Review

\title{
Cell Penetrating Peptides, Novel Vectors for Gene Therapy
}

\author{
Rebecca E. Taylor ${ }^{1}$ (D) and Maliha Zahid ${ }^{2, *}$ \\ 1 Mechanical Engineering, Biomedical Engineering and Electrical and Computer Engineering, Carnegie \\ Mellon University, Pittsburgh, PA 15213, USA; bex@andrew.cmu.edu \\ 2 Department of Developmental Biology, University of Pittsburgh School of Medicine, \\ Pittsburgh, PA 15201, USA \\ * Correspondence: maz7@pitt.edu; Tel.: +1-412-692-8893; Fax: +1-412-692-6184
}

Received: 5 February 2020; Accepted: 1 March 2020; Published: 3 March 2020

\begin{abstract}
Cell penetrating peptides (CPPs), also known as protein transduction domains (PTDs), first identified $\sim 25$ years ago, are small, 6-30 amino acid long, synthetic, or naturally occurring peptides, able to carry variety of cargoes across the cellular membranes in an intact, functional form. Since their initial description and characterization, the field of cell penetrating peptides as vectors has exploded. The cargoes they can deliver range from other small peptides, full-length proteins, nucleic acids including RNA and DNA, liposomes, nanoparticles, and viral particles as well as radioisotopes and other fluorescent probes for imaging purposes. In this review, we will focus briefly on their history, classification system, and mechanism of transduction followed by a summary of the existing literature on use of CPPs as gene delivery vectors either in the form of modified viruses, plasmid DNA, small interfering RNA, oligonucleotides, full-length genes, DNA origami or peptide nucleic acids.
\end{abstract}

Keywords: cell penetrating peptides; protein transduction domains; gene therapy; small interfering RNA

\section{Introduction}

The plasma membrane of a cell is essential to its identity and survival, but at the same time presents a barrier to intracellular delivery of potentially diagnostic or therapeutic cargoes. Therefore, the development of approaches to deliver functional cargoes, be they peptides, proteins, nucleic acids, or nanoparticles across cell membranes, a process termed protein transduction, has wide-reaching research and clinical implications. The ability of Trans-Activator of Transcription (Tat) protein of the Human Immunodeficiency Virus (HIV) to transduce cultured cells and lead to viral gene expression [1,2] without requiring a receptor was the first example of a protein that naturally employs a portion of itself to achieve cell penetration and lead to intracellular delivery of the entire HIV viral particle. The chemical cross-linking of a full-length Tat protein to multiple different proteins such as horseradish peroxidase, B-galactosidase, RNase A and domain III of Pseudomonas exotoxin A served to demonstrate the ability of Tat protein to ferry other large cargoes across the cell membrane [3]. Similarly, the homeobox Antennapedia (Antp) transcription factor of Drosophila melanogaster was demonstrated to enter nerve cells in a receptor independent manner where it could then regulate neural morphogenesis [4]. Mapping of the domains within Tat and Antp responsible for the observed transduction led to the identification of the first two cell penetrating peptides (CPPs): the 11 amino acid cationic domain of HIV-1 Tat protein (YGRKKRRQRRR) [5] and the 16 amino acid sequence from the third helix of the Antennapedia domain (RQIKIWFQNRRMKWKK) termed Antp or penetratin [6]. Subsequently, the ability of the small part of the full-length Tat protein to deliver cargoes, including other full length proteins and even large multimeric protein complexes across cell membranes in culture and in vivo following systemic 
delivery in mice [7] was documented, further highlighting the delivery potential of these unique peptides. Since then, the number of peptides, both cell-specific and non-specific, reported as having cell penetrating properties has increased exponentially [8]. This is particularly true for a wide spectrum of cationic peptides that primarily rely on their cationic charge to interact with proteoglycans on the cell surface (see below). There has been intense interest in identifying both new cell-specific CPPs, as well as strategies to make Tat and other non-specific CPPs act in a more cell-specific manner by taking advantage of tissue characteristics, mostly in the context of cancer. With the accompanying interest and explosion in the number of studies, it has become impossible to provide a comprehensive, all-encompassing single review of these unique peptides. Therefore, out of necessity, the authors chose to provide only a very broad overview of classification, mechanism of transduction and highlight applications of CPPs as vectors for gene and nucleic acid delivery only. Readers are referred to an earlier review of CPPs by the authors [8] as well as several other excellent reviews [9-11].

\section{Types of CPPs}

\subsection{Non-Cell-Specific CPPS}

CPPs are broadly categorized into non-cell-specific and cell-specific peptides with great sequence heterogeneity (Table 1). The non-cell-specific CPPs can be sub-classified into three classes: cationic, hydrophobic, and amphipathic. Tat and Antp are cationic peptides, rich in arginine and lysine, with the longer Antp peptide having a more defined 3D structure. In addition to these naturally occurring CPP sequences, synthetic cationic peptides including homopolymers of arginine [12], lysine [13] and/or the cationic, amino acid ornithine [14] were demonstrated to function as effective transduction peptides. Even histidine, which becomes protonated at low $\mathrm{pH}$, can function as a CPP at $\mathrm{pH}$ below 6.0 and has been used for delivery into tumor cells with lower $\mathrm{pH}$ [15]. Arginine-based homopolymers ranging from 6 to 12 amino acids function as CPPs with 8-10 amino acid length identified as having the highest transduction ability [16]. Similarly, 8-mer homopolymers of lysine transduce a variety of cell types with similar efficiencies as homopolymers of arginine [17]. There is a definite optimum length for these homopolymers with greater than 12 amino acids showing reduced transduction efficiency. Unlike the acute cellular toxicity elicited by long poly-lysine molecules, short lysine homopolymers (6-12 mers) have no demonstrable cytotoxic effects, even at high concentrations [13]. Thus, it appears that too little or too much cationic charge within a short region negatively affects transduction.

Amphipathic CPPs are chimeric peptides generated by attaching the hydrophobic domain of the CPP to a nuclear localizing signal (NLS) such as the SV40 NLS through a covalent bond [18]. Usually, hydrophobic CPPs are derived from signal peptide sequences. Signal peptides that allow proteins to be secreted from cells can also facilitate entry of the proteins back across the membrane into cells. Examples of hydrophobic transduction peptides identified to date include leader sequences for keratinocyte growth factor and fibroblast growth factor [19], but likely most leader sequences of secreted proteins could potentially function as CPPs.

Interestingly, even certain pathogenic bacteria use CPPs for delivery of bacterial effector proteins into different types of mammalian cells. For example, the pathogenic bacteria Yersinia enterocolitica encodes for the anti-inflammatory protein YopM with two alpha helices, $\alpha 1 \mathrm{H}$ and $\alpha 2 \mathrm{H}$, in its amino terminus that function as CPPs similar to Antp [20-22]. Similarly, Shigella and Salmonella encode for immune effector proteins that can also enter cells efficiently to modulate the immune response [22].

\subsection{Cell-Specific CPPS}

The other major sub-classification is cell-specific CPPs, identified through different screening methods including plasmid, microorganism surface, ribosome, or phage display of large peptide libraries. The advantage of this approach is that a priori knowledge of a binding partner is not necessary. Such cell-specific CPPs circumvent the issues associated with the non-cell specific CPPs, namely non-specific cellular uptake leading to off-target side effects and the need to administer high 
doses of CPPs to achieve adequate levels in target organs or cell types of interest. Such high doses are necessary in order for a small fraction of CPPs to escape the liver, kidney, and the reticuloendothelial system to reach the target organ of interest. Such an approach would be particularly troublesome if the target is the brain or a poorly vascularized tissue. Thus, developing tissue or cell-specific CPPs would be particularly attractive as it would improve the efficacy of the delivered cargo with less off-target effects while reducing the overall dose needed, which would be particularly beneficial when scaling up from small to larger animal models, and ultimately for human clinical trials.

Another approach to circumventing this issue is by delivering non-tissue specific CPP bearing cargo in a pro-drug fashion that can be activated under certain conditions or specific environments. This is only feasible if a specific cell type expresses a unique enzymatic activity such as viral or disease specific proteases [23]. Another approach is local delivery (e.g., intra-tumoral, intra-articular, intra-muscular, intra-ocular, intra-tracheal, intra-dermal, etc.) to limit the transduction activity of non-specific CPPs to specific sites. This would depend on and be limited to a specific application or situation and would be feasible only if the target cell is located in an accessible site with limited diffusion such as topical delivery for dermatological applications, the eye for ophthalmological applications [24-26], joints for arthritis/degenerative conditions [27], and directly into tumors [28].

\section{Identification of Tissue Specific CPPs}

Cell-specific CPPs were identified predominantly by using peptide phage display libraries to screen for peptides able to target specific cell types. The concept of phage display was first proposed by Smith in 1985 [29]. Following this initial report, combinatorial peptide libraries of various lengths using different types of phages (M13, T7) have been used successfully to identify peptides able to facilitate internalization of intact phage. Alternatively, plasmid, antibodies, microorganism surface or ribosome displays of peptide libraries have been employed as well. Phage display requires exposing the target cell or tissue of interest to a large, randomized phage library in which one of the envelope proteins used by the phage for internalization has been modified to display linear or cyclic peptides of various lengths and randomized amino acid sequences [30]. The internalized phage can then be isolated, expanded and used in subsequent rounds of screening. Usually 3-5 rounds of screening results in enrichment of a small number of peptides identifiable by DNA sequencing of the recovered phage. This approach requires enriching for a specific, small subset of phage from a very large library. As such, false positives are a concern and have to be discerned from phage that is indeed bound and internalized by the target cell type. One approach to circumvent this problem is to carry out the first cycle in cell culture using relevant cell types in order to reduce the likelihood of false positives. Subsequent cycles can then be carried out in vivo using the enriched pool from the in vitro cycle [30-32]. Such an approach has led to the identification of peptides targeting vascular endothelium [33], synovial tissue [27], dendritic cells [34], pancreatic islet cells [35] and cardiac myocytes [31], and has identified NRG (Asparginine-Arginine-Glycine) and RGD (Arginine-Glycine-Aspartic acid) motifs that target phage to tumor vasculature in nude tumor-bearing mice [36].

\section{Mechanisms of Transduction}

Despite intense study of CPPs, the specific pathway(s) involved in facilitating transduction remain elusive. CPPs are short in length, making the use of standard techniques for identifying binding targets on the cell surface more challenging. Additionally, their rapid cell entry, occurring within minutes at physiological conditions, makes analysis difficult. It is likely that a non-cell specific CPP such as Tat that crosses the blood brain barrier will not share a cell entry pathway with a cell-specific CPP. Even for a particular CPP the mechanism of transduction likely varies depending on the specific cargo fused to it, with changes in parameters such as local milieu and $\mathrm{pH}$ almost certainly playing a part. This is further complicated by recent data suggesting that the local concentration of a CPP may influence the internalization pathway used [37-39]. It should be noted that elucidation of the mechanism of transduction is not only of theoretical interest as the loading of cargoes must be achieved in a way as to 
not interfere with either the binding or cell internalization mechanism of CPPs. For example changing the hydrophobicity, but not the cationic charge, of a guanidine-rich homo-polymer significantly changed its transduction abilities and ability to internalize cargoes [40].

Although the exact transduction mechanism of CPPs remains elusive, extensive work from multiple investigators has shed considerable light. There is evidence both for mechanisms that are non-endocytic/energy independent or endocytic/energy-dependent [41]. The broad range of cells that are readily transducible by non-specific CPPs such as Tat suggests a role for ubiquitously shared cellular structures such as surface binding to plasma membrane phospholipids or, in particular proteoglycans through electrostatic interactions, as a first step towards cell entry [42,43]. Cell lines deficient in heparan sulfate have significantly reduced transduction by cationic peptides $[13,44,45]$. This reduction suggests that electrostatic interactions on the cell surface, separate from CPP-lipid interactions, contribute to protein transduction. It is likely that transduction is a two-step process, with the first step being electrostatic interaction of non-specific CPPs with anionic elements, such as glycosaminoglycans on the cell surface that draw the CPPs into close proximity to the plasma membrane. Subsequently, cationic CPPs bearing small cargoes likely enter cells via direct translocation, with uptake of larger cargoes mediated by micropinocytosis, a more energy-dependent and slower process [46]. Transduction has been shown to occur at $4{ }^{\circ} \mathrm{C}$ and after depletion of the adenosine triphosphate (ATP) pool [13], albeit at a reduced level, suggesting that it is not exclusively an energy-dependent process. Research also suggests that increasing hydrophobic characteristics of a CPP, as in the case of Tat, increases its efficiency as a transporter [47].

\section{Cell Penetrating Peptides as Gene Delivery Vectors}

Although CPPs have been used as vectors for delivery of drugs [48-51], other peptides of therapeutic potential [52-60], proteins [56,61-65], radioisotopes [66-69], quantum dots [70,71] and photosensitizers [72,73], this review will focus on use of CPPs as vectors for nucleic acid delivery, be they genes, oligonucleotides, peptide nucleic acid conjugates, small interfering RNA (siRNA) or the newest application with DNA origami. Although there is literature on all of these applications, most interest and work done to date has been with siRNA. The necessary factors to consider in these applications is the platform's ability to successfully conjugate nucleic acids to CPPs, escape from enzymatic degradation in serum, escape the reticuloendothelial compartments, successfully cross cell membranes, escape from endocytic degradation and, in cases of gene delivery, achieve nuclear localization. All of these hurdles have been addressed with creative strategies that we will try to summarize here. Even though CPPs are attractive alternatives to viral gene delivery, we will begin by briefly summarizing the literature on use of CPPs to modify viral vectors for the purpose of gene therapy.

\subsection{Viral Vectors}

Adenovirus is commonly employed as a vector for gene delivery due to its high transduction efficiency, although it is dependent on the presence of coxsackievirus and adenovirus receptors (CAR) for internalization. Chemical conjugation of adenovirus to Tat, octa-arginine or proline rich CPPs, led to 1-2 log-fold higher transduction of CAR-negative cells in vitro than unmodified adenovirus [74-76]. Electrostatic formation of complexes between negatively charged adenoviral particles and positively charged CPPs, such as Tat, penetratin, poly-arginine and Pep1, led to 100-fold greater transduction of CAR-negative cells compared to unmodified adenovirus, though again only in vitro [77]. In contrast, oncolytic adenovirus-serotype 5 modified to express an SCG3 promoter/ASH1 enhancer driven E1A gene expression, further modified to express Tat in the viral capsid protein, led to delays in tumor growth and prolonged survival of nude mice harboring subcutaneous human neuroblastoma xenografts [78]. In a very interesting application, brain-derived neurotrophic factor was fused with Tat and another CPP, HA2, and packaged into adeno-associated virus. Upon intranasal delivery to mice subjected to chronic mild stress, there was significant amelioration of depressive symptoms and 
increased hippocampal protein levels of brain-derived neurotrophic factor [79]. In another application, Tat was displayed on surface of MS2 bacteriophages carrying miRNA-122. Not only were there tumor inhibitory effects seen in multiple hepatocellular cancer cell lines, but also decreased tumor growth in nude mice bearing the hepatocellular cancer xenografts after they received an injection of the modified bacteriophage [80]. More recently, Sun and colleagues generated a recombinant PP7 bacteriophage using a one-plasmid double expression system to carry pre-microRNA-23b and displaying a CPP peptide that was able to inhibit hepatoma cell migration in vitro via down-regulation of liver-intestine cadherin expression [81]. Tobacco mosaic virus, a plant virus, decorated with Tat was able to carry enhanced green fluorescent protein (EGFP) silencing siRNA in vitro and to transduce EGFP expressing highly metastatic hepatocellular carcinoma cell lines in vivo in mice, with treatment for 10-days achieving over $80 \%$ EGFP-negative rates in tumors [82].

\subsection{Plasmid DNA}

As early as 2003, investigators realized the potential of delivering plasmid DNA using CPPs [83,84]. As Tat is rich in positively charged arginine and lysine residues, electrostatic interactions between Tat and negatively charged plasmid DNA allows for complexes to be formed between Luciferase or EGFP expressing plasmids and Tat. Though there was uptake in cells in vitro, it was via an endocytic pathway. Additionally, in vivo transfection rates were low with the internalization of complexes hindered by serum albumin [83]. To escape from endosomes after internalization, stearylation of CPPs has been used [85,86]. Stearyl-transportan 10 formed stable nano-complexes with plasmid DNA, was non-cytotoxic, non-immunogenic, and mediated transfer/expression of Luciferase reporter plasmid, though with only local uptake after an intra-dermal or intra-muscular injection [85]. Modifying another CPP, S4(13)-PV, with a 5 histidine residue attached to its $\mathrm{N}$-terminus resulted in successful packaging of plasmid DNA and siRNA in vitro with successful gene silencing of Survivin as compared with the unmodified SV(13)-PV [87]. Poly-lysine homopolymers have been used to condense with plasmids bearing angiotensin type II receptor using calcium chloride. This approach produced negligible cytotoxicity in four different human cell lines, successful tumor targeting, and marked attenuation of lung cancer growth in vivo [88].

Another approach used is one of dual targeting. This was achieved by synthesizing biotinylated forms of a tumor targeting peptide (CREKA) and a homo-polymer of arginine by linking them together through an avidin moiety. This complex could successfully condense with plasmid DNA carrying the p53 gene [89], with tumor regression seen in mice, but again the injections were adjacent to the tumor, bringing into question whether this reflected true targeting. Other homopolymers of arginine were synthesized with tumor targeting peptides [90] or a pro-apoptotic peptide (AVPI) [91] to enhance selective targeting of tumor cells. The latter conjugate was condensed with plasmid DNA carrying p53, to act synergistically to induce apoptosis in a multi-drug resistant breast cancer line, and indeed proved efficacious in vivo [91]. However, it is difficult to understand why these dual targeting complexes would specifically target tumors, as both poly-arginine and poly-lysine are non-specific CPPs. Excited by these reports, we constructed a tandem peptide by adding 6-arginine to the N-terminus of an optimized version of our cardiac targeting peptide (CTP-B). Based on our prior bio-distribution studies [66], this fluorescently labeled peptide was injected intravenously into mice and allowed to circulate for $15 \mathrm{~min}$. However, the conjugate peptide actually reduced cardiac uptake compared to the parent CTP-B peptide, while increasing kidney and liver uptake (Figure 1). 


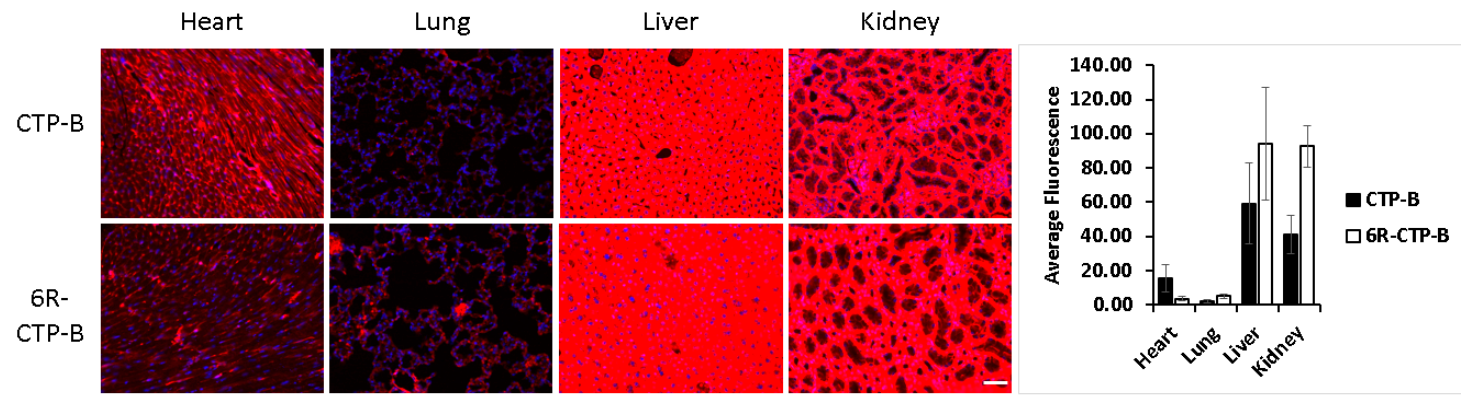

Figure 1. Fluorescent micrographs of heart, lung, liver and kidneys from mice euthanized 15 min after an intravenous injection with fluorescently labeled CTP-B or 6-Arginines-CTP-B. $N=3$ for each peptide. Scale bar represents $50 \mu \mathrm{m}$.

\subsection{Small Interfering $R N A$}

Although CPPs have been used to deliver siRNA to the heart ex vivo [92,93], or for intradermal delivery [94,95], the vast majority of applications of this approach has been in the context of cancer therapeutics. The hurdles to successful siRNA delivery are similar to delivery of plasmid DNA, namely successful conjugation to CPPs, protection from RNAses in circulation, targeted delivery to organ or cancer of interest, successful uptake, and endosomal escape. Various, creative strategies have been employed to surmount these barriers. Electrostatic charge interaction between cationic CPPs and negatively charged siRNAs have produced self-assembly of CPPs and siRNA into nanoparticles [96-99]. Escape from endosomal compartments has been achieved by acylation [99], stearylation [100] or histidine modification [101] of the N-terminus of CPPs. Histidine is purported to act as a proton pump within lysosomal compartments leading to swelling, leakiness, and bursting of these compartments releasing the $\mathrm{CPP} / \mathrm{siRNA}$ conjugate.

In vivo targeting approaches have ranged from dual targeting to dual therapies. Tumor extracellular matrix has a high level of $\alpha \mathrm{v} \beta 3 / 5$ integrin expression that binds cyclic RGD peptide. Tandem peptides combing a CPP with tumor targeting RGD through a disulfide bond complexed with anti-KRAS siRNA formed nanoparticles that significantly delayed tumor growth in a mouse model of pancreatic cancer [102]. In a similar manner, a peptide targeting epidermal growth factor, overexpressed in oral cancer cells, was conjugated to an endosomal disruptive peptide, to successfully deliver siRNA targeting cancerous inhibitor of protein phosphatase 2A (CIP2A), an oncogene [103]. The association with the siRNA was through electrostatic interactions between the peptides and siRNA when mixed in a 60:30:1 ratio with successful silencing of CIP2A in vivo in mice bearing oral cancer tumor xenografts [103]. In another report, a tumor environment responsive nanoparticle was generated, comprised of a polyethylene glycol shell with a tumor $\mathrm{pH}$-responsive polymer core. The core contained the tumor targeting RGD peptide along with homo-polymer of arginine associated through electrostatic interactions with siRNA silencing bromodomain 4 . This construct was able to inhibit prostate cancer growth significantly [97].

Differences in tumor microenvironment, like lower $\mathrm{pH}$, increased matrix metalloproteinase 2 expression and increased glutathione in the cytosol, have been employed to deliver siRNA using activatable CPPs to silence Rac1 in order to reduce hepatic metastases in colon cancer [104] and suppress c-MYC gene expression in breast cancer cell lines in vivo [105]. As anti-angiogenic therapy, stearylated poly-arginine was modified with histidine, loaded with anti-VEGF siRNA through electrostatic interaction, and Fausidil, a selective Rho-kinase inhibitor. In vitro and in vivo studies showed strong efficacy for cellular uptake and tumor growth inhibition [101]. 


\subsection{Nanoparticles}

As liposomes are a subset of nanoparticles (NPs), in this section we will focus on selected literature pertaining to non-lipid-based NPs modified in various ways with CPPs that showed efficacy in vivo. Targeting of NPs has been studied largely in the context of tumor therapies using Tat or homopolymers of arginine of various lengths. As both of these are non-cell specific CPPs, investigators have harnessed tumor environment specific properties, such as lower $\mathrm{pH}$, increased matrix metalloproteinase 2 expression and increased redox potential, to make these non-specific CPPs act in a more tumor-specific manner. In one of the earliest studies, cationic NPs composed of $\beta$-cyclodextrin and low-molecular weight polyethylenimine were labeled with both octa-arginine and folic acid to deliver plasmid DNA to folate-receptor positive tumor cells, both in vitro and in vivo [106]. In another application gelatin-silica NPs were modified with different CPPs, including a fusogenic peptide comprised of Tat and influenza hemaglutanin A2, to successfully deliver plasmid DNA with endosomal escape and nuclear targeting properties in vivo [107]. A tumor activatable CPP dual-triggered by lowered $\mathrm{pH}$ and matrix metalloproteinase 2 was used to label NPs carrying dual anti-tumor therapies, doxorubicin and siRNA targeting vascular endothelial growth factor. This led to effective shut down of blood vessel formation and to apoptosis within the tumor [108]. In another approach, NPs were modified with photo- and pH-responsive CPPs. The cell penetrating ability of the cationic CPPs was quenched by a $\mathrm{pH}$-sensitive, negatively charged inhibitory peptide that was released in the lower $\mathrm{pH}$ microenvironment of the tumor. These NPs, loaded with siRNA, accumulated within tumor cells upon near-infrared light illumination, resulting in increased antitumor efficacy in vivo [109]. Another approach employed was PEGylation of glycosaminoglycan-binding peptides coupled with DNA through electrostatic charge interactions, which formed NPs that targeted bronchial epithelial cell lines with precision cut lung slices in vitro showing that PEGylation rates of $>40 \%$ were the optimal formulation [110]. Additionally, PEGylated supra-magnetic iron oxide NPs [111,112], Nobel metal NPs [113] or gold particles [114] have also been modified with CPPs to show internalization into tumor or stem cells. These latter studies were, however, all in vitro.

\subsection{Liposomes}

Cationic liposomes (LP) form spontaneous complexes with nucleic acids, which can be sterically stabilized through PEGylation. One study explored the modification of such LPs with CPPs and found that full peptide coverage resulted in less internalization into cells than intermediate coverage, with optimum coverage being cell specific [115]. Additionally, cationic LPs, though effective in vitro, have demonstrated significant cytotoxicity in vivo. This issue can be addressed by using neutral PEGylated LPs modified by CPPs. In one study, neutral PEGylated LPs modified by octa-arginine homo-polymer showed negligible cytotoxicity, enhanced cellular association, and gene silencing capacity in vitro [116]. Harnessing the increased redox milieu of tumors, a Tat-functionalized LP was loaded with paclitaxel, a common cancer chemotherapeutic, with Tat conjugated to a pegylated (PEG) moiety through a cleavable disulfide linker. At the tumor site, PEG was detached by exogenous reducing agent glutathione, resulting in exposure of Tat, with subsequent enhanced tumor uptake and inhibition of proliferation of murine melanoma cell lines, both in vitro and in vivo [117]. In another approach, alanine-alanine-asparagine, a substrate for the endoprotease legumain, was added to the fourth lysine of Tat leading to a branched peptide version. This modified branching Tat peptide was used to label LPs loaded with doxorubicin, leading to decreased non-specific uptake and increased uptake by tumor cells, resulting in increase in anti-tumor activity and decrease in systemic side effects [118]. These data again demonstrate the ability to harness the cell penetrating capabilities of a non-specific CPP such as Tat in a tumor environment specific manner. 


\subsection{DNA Origami}

DNA nanostructures, first described by Nadrian Seeman [119], are novel structures formed by the hybridization of multiple single-stranded DNA (ssDNA) oligomers to create a variety of precise structures, with structure, size, and capabilities of DNA nanofabrication growing significantly in the intervening years (Figure 2A,B). In particular, the development of scaffolded DNA origami by Rothemund uses long ssDNA, typically from the M13 bacteriophage, in combination with hundreds of short ssDNAs that act as "staples" to form nanostructures with arbitrary shapes (Figure 2D) [120]. Approaches using only short ssDNA also demonstrated capability of forming two-dimensional [121,122] and three-dimensional structures (Figure 2C,E) [123,124]. Together, these methods treat DNA as a biopolymer, and its information-containing structure is used to drive nanostructure assembly. These DNA origami platforms can be decorated with biomolecules, including peptides, proteins, and functional molecules including fluorophores, aptamers, quantum dots, and gold nanoparticles, allowing them the ability to target cells $[125,126]$. In one example, the efficiency of intracellular delivery of DNA origami could be increased 22-fold when it was decorated with the iron transport protein transferrin, with efficiency increasing with increasing number of transferrin molecules attached [127]. The versatility of decoration of DNA origami has enabled the co-delivery of chemotherapeutics along with gene therapy. Liu et al. recently demonstrated the delivery of both doxorubicin and the p53 gene using a triangular DNA origami platform decorated with multiple targeting aptamers (Figure 3A) [128].

(A)

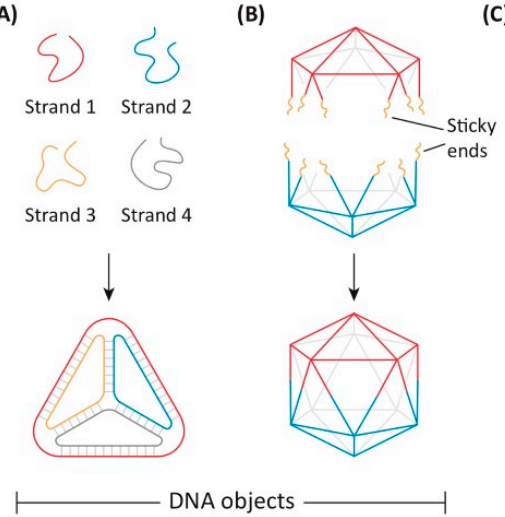

(C)

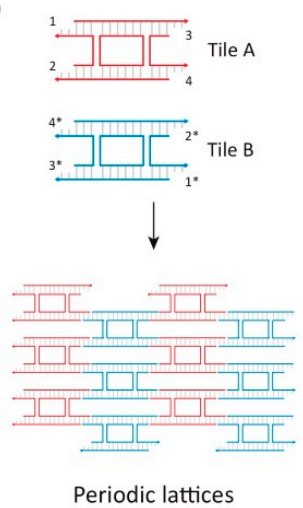

(D)

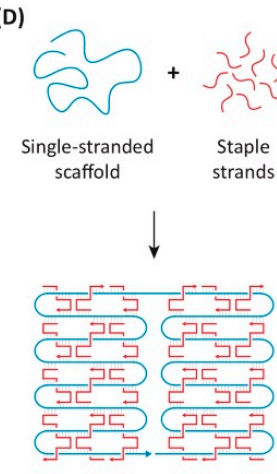

DNA origami
(E)

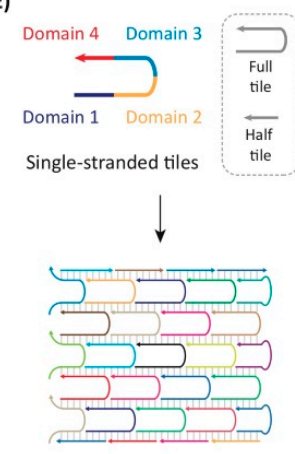

DNA bricks

Figure 2. Structural DNA nanotechnology approaches for drug delivery. Common methods for creating DNA nanostructures include $(\mathbf{A}, \mathbf{B})$ junction and lattice-based structures like DNA nanocages, (C) periodic lattices, (D) scaffolded DNA origami and (E) scaffold-free assembly of single-stranded tiles (SSTs), otherwise known as DNA "DNA bricks". Panels (A through E) reprinted with permission from Madhanagopal, B. R. et al. [129]. Copyright 2018, Elsevier.

To date, only a few DNA nanotechnology studies used CPPs. One study used gold nanoparticles coated with CPP-decorated filamentous DNA origami to create a 3D superstructure with high transduction efficiency [130]. This approach demonstrated the versatility of DNA nanotechnology and its potential for cellular imaging and drug delivery [130]. Another multivalent approach for CPP and structural DNA nanotechnology used both aptamers and CPP to target Ramos cells and then drive the nanopore-like structure into the tumor cells [131]. The combination of aptamers with CPP in this study showed improved cellular uptake and targeting. DNA tetrahedrons have been used as vehicle for delivering siRNAs into cells to silence genes [132], and for the purpose of optimizing delivery, numerous targeting cationic and amphipathic CPPs including Tat, penetratin, and MAP were used. However, likely due to the overexpression of folate receptors in tumor membranes, decoration with folate as a targeting model produced more efficient uptake than platforms decorated with CPPs. In another application, a gammaPNA $(\gamma \mathrm{PNA})$ hairpin was used to create a non-covalently cyclized form of Tat to enhance cell uptake [133]; when DNA tetrahedra were used to increase the multi-valency of this approach, cellular delivery efficiency increased further (Figure 3B). 


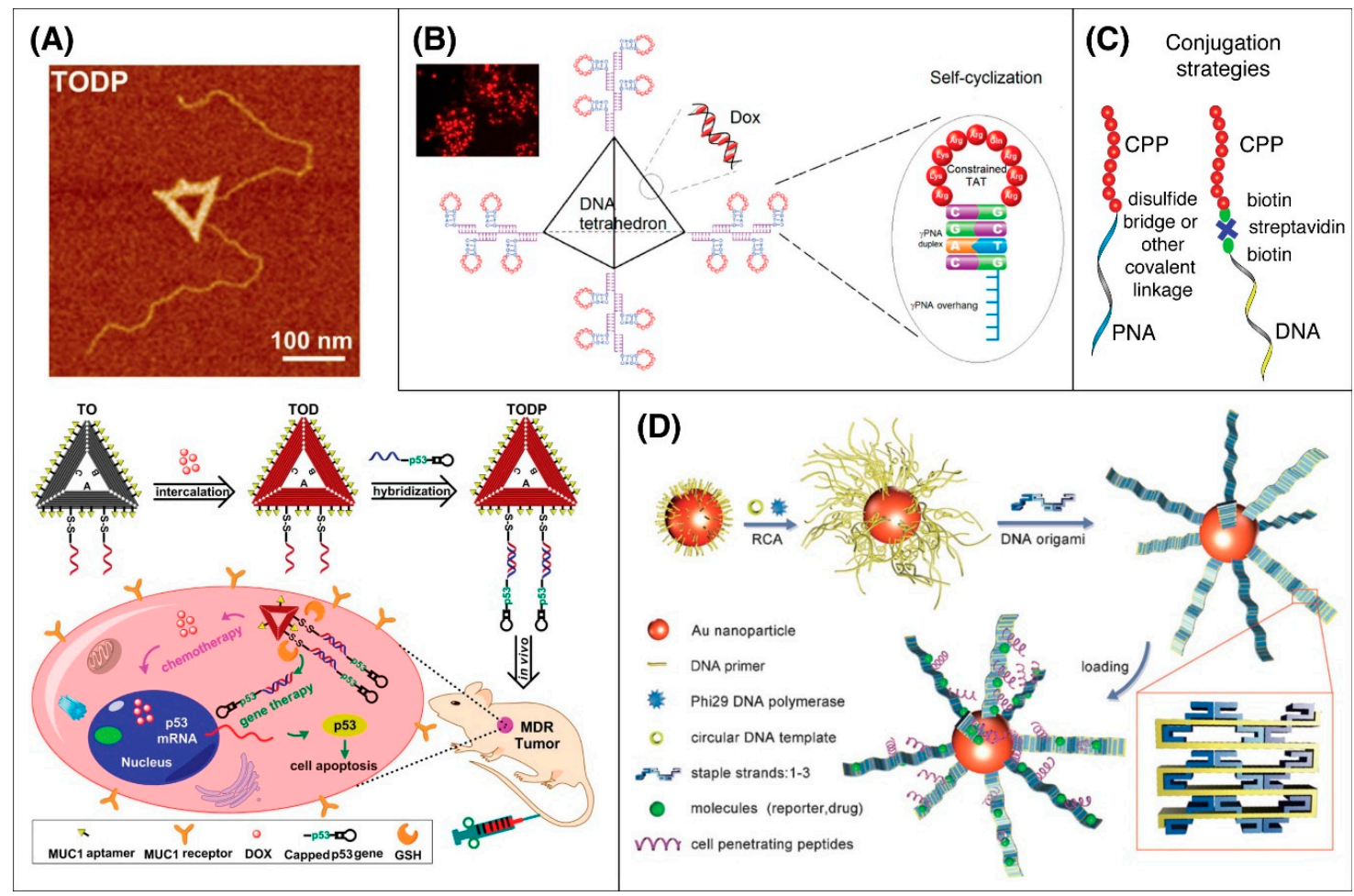

Figure 3. Drug delivery nanostructures can integrate multiple types of functional decoration and for cell-specific and high-efficiency transduction. (A) Decoration with MUC1 aptamers, DOX, and p53 gene cassettes enabled a DNA origami triangular construct to target tumor cells and delivery a combination therapy of chemotherapy agent DOX alongside p53 genes. Reprinted with permission from Liu, J. et al. [128]. Copyright 2018, American Chemical Society. (B) DNA tetrahedron structures were decorated with both DOX and Tat cell targeting peptides for targeted therapy. When Tat peptides were self-cyclized by the hybridization of short flanking $\gamma$ PNAs, the self-cyclized Tat constructs were taken up at 10-fold higher rates. Reprinted with permission from Tan, X. et al. [133]. Copyright 2018, American Chemical Society. (C) While CPP is typically conjugated to peptide nucleic acids (PNA) using disulfide bonds or other covalent methods, CPP is typically ionically bound to PNA using biotin-streptavidin attachment. (D) CPP-decorated DNA origami ribbons and gold nanoparticles were used together to create superstructures with high molecular loading capacity for both cellular imaging and drug delivery. Reprinted with permission from Yan, J. et al. [130]. Copyright 2015, John Wiley and Sons.

Like a "Swiss army knife" with many capabilities, DNA nanotechnology has the potential to create multivalent, dynamic and responsive gene delivery platforms capable of unprecedented control over targeting and delivery while integrating multiple distinct approaches using CPPs [134,135]. However, for optimization of this technology, robust and low-cost stabilization methods are critical for protecting DNA origami from low salt denaturation and enzymatic degradation in vivo.

\subsection{Peptide Nucleic Acids}

Peptide nucleic acids (PNAs) are peptide-like polymers with nucleic acid side chains. PNAs were first developed as a synthetic DNA mimic in which the deoxyribose phosphate backbone was replaced with an uncharged and achiral polyamide backbone [136]. With a similar axial rise and identical nucleobase side chains, PNAs are notable for their capacity to bind DNA with extraordinarily high affinity [137-141]. Furthermore, the pseudopeptide backbone of PNA is not a substrate for nucleases or proteases [137], giving them stability and potential to form nano-systems with "trojan horse"-like properties. Without modification, PNAs are not readily taken up by cells in vivo [142], but covalent conjugation to CPPs is straight-forward since both can be made using solid phase peptide synthesis 
(Figure 2C). In practice however, CPPs and PNAs are often separately synthesized and then conjugated via a disulfide bond [143]. Depending on the PNA nucleobase composition, they are capable of binding to complementary DNA and RNA via both Watson-Crick and Hoogsteen base pairing rules [144]. Important for cell delivery applications like gene therapy, covalent linkage to CPPs does not reduce the biological activity of uncharged PNA [142]. Once inside the cell, PNAs are well-suited for the steric blocking method of gene expression control, since they bind tightly to RNA and DNA while resisting degradation.

The 16-residue CPP penetratin has most commonly been studied in PNA-CPP conjugates [145]. Notably, PNA-penetratin studies showed that the CPP does not interfere with the binding of PNA to target DNA [146], but later studies did find that cellular uptake of PNA-penetratin varies as a function of cell type, temperature and concentration [143]. The first demonstration of targeted delivery of CPP-coupled PNA came in 1998 when penetratin and transportan were covalently coupled to a 21mer PNA [147]. These conjugates showed efficient uptake in Bowes melanoma cells, binding to mRNA and blocking galanin gene expression to modify pain response. Another study demonstrated that PNA coupled to a retro-inverso delivery peptide were rapidly taken up by neurons, and that these antisense conjugates were able to depress the amount of target mRNA in culture [148]. Dragulescu-Andrasi et al. created cell-permeable guanidine-based PNA-oligoarginine analogues [149]. Gamma-position modifications with L-serine [150] and hydrophilic (R)-diethylene glycol "miniPEG" [141] were able to pre-organize these $\gamma$ PNAs into helical structures with higher binding affinity and higher solubility. Modification of PNA may also reduce the required dose of PNA in therapeutic applications, because such modification can decrease the rate of physiological clearance [151]. Endosomal escape remains a challenge for PNA-CPP conjugates post-endocytosis, which further necessitates high dose administration. To increase therapeutic efficacy, CPP-PNAs can be co-administered with chloroquine or $\mathrm{Ca}^{2+}$ to facilitate conjugate escape into the cytosol [152].

A strategy combining DNA nanotechnology, PNAs and CPPs to form NPs has shown promising results with integration of modified $\gamma$ PNAs further improving cellular uptake [153]. Specialized NPs using DNA nanotechnology offer unique opportunities for compactly integrating precise ratios and arrangements of distinct functional molecules such as PNA and CPP onto DNA nanostructures. As mentioned in the previous section, one such approach was a DNA tetrahedron-based beacon decorated with Tat flanked by short complementary $\gamma$ PNAs (Figure 3B) [133]. In this study, as the complementary $\gamma$ PNAs hybridized, they formed a hairpin causing the CPP to "self-cyclize" to form into a conformationally constrained and higher activity state. Uptake studies of the beacon system showed a 10-fold increase in uptake of self-cyclized Tat-PNA systems as compared with linear ones.

\subsection{CRISPR-Cas}

CRISPR-Cas (clustered, regularly interspaced, short palindromic repeats-associated system) represents an efficient tool for gene editing and consists of a guide RNA and the Cas9 protein delivered to cells using either plasmid or virus-based vectors. However, using CPPs, direct delivery leads to less cellular toxicity, and fewer off-target mutations [154-156] as well as delivery to hard-to-transfect cell lines [157]. Protocols were optimized to use this approach [158].

\section{Hurdles to Clinical Application}

Few clinical trials using CPPs have been published to date, mostly in the context of cancer diagnosis and therapeutics [159-161]. Twenty-seven patients with breast cancer received intra-operative activatable fluorescent peptide to improve tumor margin detection and assist with complete tumor resection [162]. Intraoperative imaging of surgical specimens allowed for real-time tumor detection and tumor-free margin resection [162]. Another small trial of 31 patients undergoing coronary artery angioplasty used the cell penetrating lipopeptide protease-activated receptor-1-based pepducin as an anti-platelet agent and this approach was demonstrated to be safe [163]. However, the trial was too small to assess whether this offered superior therapeutic outcomes over standard therapies. 
AVI-5126 is a CPP conjugated to a morpholino designed to knock-down the human C-MYC gene. It was the first CPP-conjugated morpholino tested in a safety and efficacy clinical trial to prevent blockage of veins harvested for cardiovascular bypass surgery by inhibiting cell proliferation. The vein was excised and immersed in a solution containing $10 \mathrm{mM}$ AVI-5126 and then re-implanted as a bypass graft. The study, titled "Clinical Study to Assess the Safety and Efficacy of ex-Vivo Vein Graft Exposure to AVI-5126 in Coronary Artery By-Pass Grafting to Reduce Clinical Graft Failure", was terminated early, not due to safety concerns, but due to low likelihood of clinical efficacy. The same CPP and morpholino conjugate were also tested in a restenosis of coronary artery after balloon angioplasty trial, enrolling 30 patients, but it was terminated for unknown reasons with no safety or efficacy data published. It is possible that the advent of drug-eluting stents and their remarkable efficacy has reduced the interest in the clinical development of this conjugate.

Give the small number of clinical trials with CPPs, there clearly are significant issues to overcome before clinical use of CPP-based therapeutics becomes a reality. The first issue is the potential immunogenicity of the CPP containing protein or peptide, especially for chronic or repetitive treatments. It is unlikely that the small CPPs themselves would be immunogenic, but their cargoes can vary in size and the novel antigenic epitopes generated by fusion with the CPP could theoretically pose an issue. The second issue is lack of oral bioavailability of CPPs linked to their cargoes, and hence need for either topical or intravenous administration. One exception may be cyclized arginine rich CPPs with Dor L-naphthylalanine that showed some evidence of oral bioavailability with increased endosomal escape and improved cytosolic delivery [164]. The third issue, as discussed above, is the lack of cell specificity for the cationic and hydrophobic CPPs. The lack of specificity decreases the therapeutic window, increasing the dose used and hence potential for adverse effects. Fourth, since the two major routes of elimination for CPPs are the kidney and liver, analysis of toxicity of a CPP-based therapeutic in these and other tissues is required by the FDA prior to initiation of clinical trials. The testing of CPP-based therapeutics has to be carried out under Good Laboratory Practices (GLP) conditions and pharmacology/toxicity analyses by a GLP certified lab can be prohibitively expensive, with few federal, non-private funding mechanisms available. Lastly, CPP-based therapeutics will likely be expensive to produce and the cost of the therapeutic could be an issue, especially when treating a chronic condition that requires frequent dosing for extended time-periods. As a reference, it is estimated to typically take 2.6 billion US dollars to bring a therapeutic to market. However, depending on efficacy and targeting, especially for cancers where therapies are time-limited, the cost-benefit ratio could be very favorable. For other conditions, delivering cargoes that last a few weeks or months, like siRNA, could reduce the frequency of administration, and potentially reduce treatment costs.

Table 1. Classification of Cell Penetrating Peptides.

\begin{tabular}{ccc}
\hline CPPs-Non-Tissue Specific & Peptide Sequence & Origin \\
\hline Cationic & & \\
\hline Tat [5] & GRKKRRQRRRPPQ & HIV Tat Protein \\
Ant [6] & RQIKIWFQNRRMKWKK & Antennapedia homeodomain \\
8-Arginine [12] & RRRRRRRR \\
8-Lysine [13] & KKKKKKKK & n/a \\
PTD-5 [17] & RRQRRTSKLMKR & Phage display \\
\hline Hydrophobic & & \\
\hline Transportan [165] & GWTLNSAGYLLGKINLKALAALAKKIL & Galanin and mastoparan \\
MAP [166] & KLALKLALKALKAALKLA & Galanin and mastoparan \\
TP10 [167] & AGYLLGKINLKALAALAKKIL & \\
Pep-7 [168] & SDLWEMMMVSLACQY & CHL8 peptide \\
\hline
\end{tabular}


Table 1. Cont.

\begin{tabular}{ccc}
\hline CPPs-Non-Tissue Specific & Peptide Sequence & Origin \\
\hline Amphipathic & & \\
\hline Azurin p18 [169] & LSTAADMQGVVTDGMASG & Azurin \\
Azurin p28 [170] & LSTAADMQGVVDGMASGLDKDYLKPDD & Azurin \\
hCT18-32 [171] & KFHTFPQTAIGVGAP & Calcitonin \\
Bac 7 [172] & RRIRPRPPRLPRRPRPLPFPRPG & Bactenecin \\
\hline CPPs-Tissue Specific & Peptide Sequence & Origin \\
\hline CTP [31,66] & APWHLSSQYSRT & Phage display \\
K5-FGF [173] & AAVALLPAVLLALLP & Phage display \\
HAP-1 [27] & SFHQFARATLAS & Phage display \\
293P-1 [174] & SNNNVRPIHIWP & Phage display \\
Vascular Endothelium [33] & SIGYPLP & Phage display \\
\hline
\end{tabular}

\section{Summary}

The identification of cell penetrating peptides (CPP) or protein transduction domains (PTD) a quarter of a century ago has opened up new avenues to deliver peptides, proteins, nucleic acids, and nanoparticles, including viral particles, more efficiently into cells. Tissue specific CPPs, as well as non-specific CPPs that were engineered to target certain cell types, show great potential for clinical use. Their utility in diagnostic imaging is already being realized in the arena of tumor imaging. Despite the myriad positive results using CPPs in pre-clinical models for diagnosis and/or treatment of disease, the clinical applications of CPPs have been slow to develop due to the many hurdles to implementing new therapeutics.

\section{Patents}

M.Z. and Paul D. Robbins (University of Minnesota, Minnesota, MN, USA) hold a patent on the use of cardiac targeting peptide as a cardiac vector (Cardiac-specific protein targeting domain, U.S. Patent Serial No. 9249184).

Author Contributions: R.E.T. contributed the sections on DNA origami and peptide nucleic acids, as well as the graphical abstract, and provided critical review of the rest of the sections. M.Z. provided the rest of the sections. All authors have read and agreed to the published version of the manuscript.

Funding: M.Z. is supported by American Heart Association Scientist Development Award 17SDG33411180, and by a grant awarded under the Pitt Innovation Challenge (PinCh) through the Clinical and Translational Science Institute of the University of Pittsburgh, through National Institutes of Health, UL1TR001857. R.E.T. is supported in part by National Science Foundation grants 1739308 and 1944130 and by the Air Force Office of Scientific Research grant number FA9550-18-1-0199.

Acknowledgments: The authors would like to thank Raymond A. Frizzell and Bruce Armitage for their insightful reviews of the manuscript.

Conflicts of Interest: M.Z. also serves as Chief Scientific Officer and is on the Board of Directors of the startup Vivasc Therapeutics Inc. and holds substantial future equity in it. This company had no role in the design of the study or writing of this review; in the collection, analyses or interpretation of the data presented; in the writing of the manuscript, and in the decision to publish the results.

\section{References}

1. Frankel, A.D.; Pabo, C.O. Cellular uptake of the tat protein from human immunodeficiency virus. Cell 1988, 55, 1189-1193. [CrossRef]

2. Green, M.; Loewenstein, P.M. Autonomous functional domains of chemically synthesized human immunodeficiency virus tat trans-activator protein. Cell 1988, 55, 1179-1188. [CrossRef]

3. Fawell, S.; Seery, J.; Daikh, Y.; Moore, C.; Chen, L.L.; Pepinsky, B.; Barsoum, J. Tat-mediated delivery of heterologous proteins into cells. Proc. Natl. Acad. Sci. USA 1994, 91, 664-668. [CrossRef] [PubMed]

4. Joliot, A.; Pernelle, C.; Deagostini-Bazin, H.; Prochiantz, A. Antennapedia homeobox peptide regulates neural morphogenesis. Proc. Natl. Acad. Sci. USA 1991, 88, 1864-1868. [CrossRef] [PubMed] 
5. Green, M.; Ishino, M.; Loewenstein, P.M. Mutational analysis of HIV-1 Tat minimal domain peptides: Identification of trans-dominant mutants that suppress HIV-LTR-driven gene expression. Cell 1989, 58, 215-223. [CrossRef]

6. DeRossi, D.; Joliot, A.H.; Chassaing, G.; Prochiantz, A. The third helix of the Antennapedia homeodomain translocates through biological membranes. J. Biol. Chem. 1994, 269, 10444-10450.

7. Schwarze, S.R. In Vivo Protein Transduction: Delivery of a Biologically Active Protein into the Mouse. Science 1999, 285, 1569-1572. [CrossRef]

8. Zahid, M.; Robbins, P.D. Cell-Type Specific Penetrating Peptides: Therapeutic Promises and Challenges. Molecules 2015, 20, 13055-13070. [CrossRef]

9. Feni, L.; Neundorf, I.; Sunna, A.; Care, A.; Bergquist, P.L. The Current Role of Cell-Penetrating Peptides in Cancer Therapy. Adv. Exp. Med. Biol. 2017, 1030, 279-295.

10. Guidotti, G.; Brambilla, L.; Rossi, D. Cell-Penetrating Peptides: From Basic Research to Clinics. Trends Pharmacol. Sci. 2017, 38, 406-424. [CrossRef]

11. Kalafatovic, D.; Giralt, E. Cell-Penetrating Peptides: Design Strategies beyond Primary Structure and Amphipathicity. Molecules 2017, 22, 1929. [CrossRef] [PubMed]

12. Wender, P.A.; Mitchell, D.J.; Pattabiraman, K.; Pelkey, E.T.; Steinman, L.; Rothbard, J.B. The design, synthesis, and evaluation of molecules that enable or enhance cellular uptake: Peptoid molecular transporters. Proc. Natl. Acad. Sci. USA 2000, 97, 13003-13008. [CrossRef] [PubMed]

13. Mai, J.C.; Shen, H.; Watkins, S.C.; Cheng, T.; Robbins, P.D. Efficiency of Protein Transduction Is Cell Type-dependent and Is Enhanced by Dextran Sulfate. J. Biol. Chem. 2002, 277, 30208-30218. [CrossRef]

14. Madani, F.; Lindberg, S.; Langel, Ü.; Futaki, S.; Gräslund, A. Mechanisms of Cellular Uptake of Cell-Penetrating Peptides. J. Biophys. 2011, 2011,1-10. [CrossRef]

15. Fei, L.; Yap, L.-P.; Conti, P.S.; Shen, W.-C.; Zaro, J.L. Tumor targeting of a cell penetrating peptide by fusing with a pH-sensitive histidine-glutamate co-oligopeptide. Biomaterials 2014, 35, 4082-4087. [CrossRef]

16. Tunnemann, G.; Ter-Avetisyan, G.; Martin, R.M.; Stockl, M.; Herrmann, A.; Cardoso, M.C. Live-cell analysis of cell penetration ability and toxicity of oligo-arginines. J. Pept. Sci. 2008, 14, 469-476. [CrossRef]

17. Mi, Z.; Mai, J.; Lu, X.; Robbins, P.D. Characterization of a Class of Cationic Peptides Able to Facilitate Efficient Protein Transduction in Vitro and in Vivo. Mol. Ther. 2000, 2, 339-347. [CrossRef]

18. Xu, Y.; Liang, W.; Qiu, Y.; Cespi, M.; Palmieri, G.F.; Mason, A.J.; Lam, J.K. Incorporation of a Nuclear Localization Signal in pH Responsive LAH4-L1 Peptide Enhances Transfection and Nuclear Uptake of Plasmid DNA. Mol. Pharm. 2016, 13, 3141-3152. [CrossRef]

19. Nakayama, F.; Yasuda, T.; Umeda, S.; Asada, M.; Imamura, T.; Meineke, V.; Akashi, M. Fibroblast growth factor-12 (FGF12) translocation into intestinal epithelial cells is dependent on a novel cell-penetrating peptide domain: Involvement of internalization in the in vivo role of exogenous FGF12. J. Biol. Chem. 2011, 286, 25823-25834. [CrossRef]

20. Höfling, S.; Scharnert, J.; Cromme, C.; Bertrand, J.; Pap, T.; Schmidt, M.A.; Rüter, C. Manipulation of pro-inflammatory cytokine production by the bacterial cell-penetrating effector protein YopM is independent of its interaction with host cell kinases RSK1 and PRK2. Virulence 2014, 5, 761-771. [CrossRef]

21. Gomarasca, M.; Martins, T.F.C.; Greune, L.; Hardwidge, P.R.; Schmidt, M.A.; Rüter, C. Bacterium-Derived Cell-Penetrating Peptides Deliver Gentamicin to Kill Intracellular Pathogens. Antimicrob. Agents Chemother. 2017, 61, e02545-16. [CrossRef]

22. Norkowski, S.; Körner, B.; Greune, L.; Stolle, A.-S.; Lubos, M.-L.; Hardwidge, P.R.; Schmidt, M.A.; Rüter, C. Bacterial LPX motif-harboring virulence factors constitute a species-spanning family of cell-penetrating effectors. Cell. Mol. Life Sci. 2017, 75, 2273-2289. [CrossRef]

23. Braun, G.B.; Sugahara, K.N.; Yu, O.M.; Kotamraju, V.R.; Mölder, T.; Lowy, A.M.; Ruoslahti, E.; Teesalu, T. Urokinase-controlled tumor penetrating peptide. J. Control. Release 2016, 232, 188-195. [CrossRef]

24. De Cogan, F.; Hill, L.J.; Lynch, A.; Morgan-Warren, P.J.; Lechner, J.; Berwick, M.R.; Peacock, A.; Chen, M.; Scott, R.; Xu, H.; et al. Topical Delivery of Anti-VEGF Drugs to the Ocular Posterior Segment Using Cell-Penetrating Peptides. Investig. Opthalmol. Vis. Sci. 2017, 58, 2578. [CrossRef]

25. Tai, L.; Liu, C.; Jiang, K.; Chen, X.; Wei, G.; Lu, W.; Pan, W. Noninvasive delivery of oligonucleotide by penetratin-modified polyplexes to inhibit protein expression of intraocular tumor. Nanomed. Nanotechnol. Biol. Med. 2017, 13, 2091-2100. [CrossRef] 
26. Ildefonso, C.J.; Jaime, H.; Brown, E.E.; Iwata, R.L.; Ahmed, C.M.; Massengill, M.T.; Biswal, M.R.; Boye, S.E.; Hauswirth, W.; Ash, J.D.; et al. Targeting the Nrf2 Signaling Pathway in the Retina WIth a Gene-Delivered Secretable and Cell-Penetrating Peptide. Investig. Opthalmol. Vis. Sci. 2016, 57, 372-386. [CrossRef]

27. Mi, Z.; Lu, X.; Mai, J.C.; Ng, B.G.; Wang, G.; Lechman, E.R.; Watkins, S.C.; Rabinowich, H.; Robbins, P.D. Identification of a synovial fibroblast-specific protein transduction domain for delivery of apoptotic agents to hyperplastic synovium. Mol. Ther. 2003, 8, 295-305. [CrossRef]

28. Mai, J.C.; Mi, Z.; Kim, S.H.; Ng, B.; Robbins, P.D. A proapoptotic peptide for the treatment of solid tumors. Cancer Res. 2001, 61, 7709-7712.

29. Smith, G. Filamentous fusion phage: Novel expression vectors that display cloned antigens on the virion surface. Science 1985, 228, 1315-1317. [CrossRef]

30. Zahid, M.; Robbins, P.D. Identification and Characterization of Tissue-Specific Protein Transduction Domains Using Peptide Phage Display. Adv. Struct. Saf. Stud. 2010, 683, 277-289.

31. Zahid, M.; Phillips, B.E.; Albers, S.M.; Giannoukakis, N.; Watkins, S.C.; Robbins, P.D. Identification of a Cardiac Specific Protein Transduction Domain by In Vivo Biopanning Using a M13 Phage Peptide Display Library in Mice. PLoS ONE 2010, 5, e12252. [CrossRef] [PubMed]

32. Hyvönen, M.; Laakkonen, P. Identification and Characterization of Homing Peptides Using In Vivo Peptide Phage Display. Adv. Struct. Saf. Stud. 2015, 1324, 205-222.

33. Nicklin, S.A.; White, S.; Watkins, S.J.; Hawkins, R.E.; Baker, A.H. Selective targeting of gene transfer to vascular endothelial cells by use of peptides isolated by phage display. Circulation 2000, 102, 231-237. [CrossRef] [PubMed]

34. Chamarthy, S.P.; Jia, L.; Kovacs, J.R.; Anderson, K.R.; Shen, H.; Firestine, S.M.; Meng, W.S. Gene delivery to dendritic cells facilitated by a tumor necrosis factor alpha-competing peptide. Mol. Immunol. 2004, 41, 741-749. [CrossRef] [PubMed]

35. Rehman, K.K.; Bai, X.-Y.; Miao, D.; Goltzman, D.; Karaplis, A.C. Protection of Islets byin SituPeptide-mediated Transduction of the Ikappa Kinase Inhibitor Nemo-binding Domain Peptide. J. Biol. Chem. 2003, 278, 9862-9868. [CrossRef] [PubMed]

36. Arap, W.; Pasqualini, R.; Ruoslahti, E. Cancer Treatment by Targeted Drug Delivery to Tumor Vasculature in a Mouse Model. Science 1998, 279, 377-380. [CrossRef]

37. Magzoub, M.; Eriksson, L.E.G.; Gräslund, A. Conformational states of the cell-penetrating peptide penetratin when interacting with phospholipid vesicles: Effects of surface charge and peptide concentration. Biochim. Biophys. Acta 2002, 1563, 53-63. [CrossRef]

38. Jiao, C.-Y.; Delaroche, D.; Burlina, F.; Alves, I.; Chassaing, G.; Sagan, S. Translocation and Endocytosis for Cell-penetrating Peptide Internalization. J. Biol. Chem. 2009, 284, 33957-33965. [CrossRef]

39. Gump, J.M.; June, R.K.; Dowdy, S.F. Revised role of glycosaminoglycans in TAT protein transduction domain-mediated cellular transduction. J. Biol. Chem. 2009, 285, 1500-1507. [CrossRef]

40. Backlund, C.; Takeuchi, T.; Futaki, S.; Tew, G.N. Relating structure and internalization for ROMP-based protein mimics. Biochim. Biophys. Acta 2016, 1858, 1443-1450. [CrossRef]

41. Illien, F.; Rodriguez, N.; Amoura, M.; Joliot, A.; Pallerla, M.; Cribier, S.; Burlina, F.; Sagan, S. Quantitative fluorescence spectroscopy and flow cytometry analyses of cell-penetrating peptides internalization pathways: Optimization, pitfalls, comparison with mass spectrometry quantification. Sci. Rep. 2016, 6, 36938. [CrossRef]

42. Åmand, H.L.; Rydberg, H.A.; Fornander, L.H.; Lincoln, P.; Nordén, B.; Esbjörner, E.K. Cell surface binding and uptake of arginine- and lysine-rich penetratin peptides in absence and presence of proteoglycans. Biochim. Biophys. Acta (BBA) Biomembr. 2012, 1818, 2669-2678. [CrossRef]

43. Takechi, Y.; Tanaka, H.; Kitayama, H.; Yoshii, H.; Tanaka, M.; Saito, H. Comparative study on the interaction of cell-penetrating polycationic polymers with lipid membranes. Chem. Phys. Lipids 2012, 165, 51-58. [CrossRef]

44. Rusnati, M.; Coltrini, D.; Oreste, P.; Zoppetti, G.; Albini, A.; Noonan, D.; d'Adda di Fagagna, F.; Giacca, M.; Presta, M. Interaction of HIV-1 Tat protein with heparin. Role of the backbone structure, sulfation, and size. J. Biol. Chem. 1997, 272, 11313-11320. [CrossRef]

45. Tyagi, M.; Rusnati, M.; Presta, M.; Giacca, M. Internalization of HIV-1 Tat Requires Cell Surface Heparan Sulfate Proteoglycans. J. Biol. Chem. 2000, 276, 3254-3261. [CrossRef]

46. Ma, D.-X.; Shi, N.-Q.; Qi, X. Distinct transduction modes of arginine-rich cell-penetrating peptides for cargo delivery into tumor cells. Int. J. Pharm. 2011, 419, 200-208. [CrossRef] 
47. Li, Y.; Rosal, R.V.; Brandt-Rauf, P.W.; Fine, R.L. Correlation between hydrophobic properties and efficiency of carrier-mediated membrane transduction and apoptosis of a p53 C-terminal peptide. Biochem. Biophys. Res. Commun. 2002, 298, 439-449. [CrossRef]

48. Nguyen, L.T.; Yang, X.-Z.; Du, X.; Wang, J.-W.; Zhang, R.; Zhao, J.; Wang, F.-J.; Dong, Y.; Li, P.-F. Enhancing tumor-specific intracellular delivering efficiency of cell-penetrating peptide by fusion with a peptide targeting to EGFR. Amino Acids 2015, 47, 997-1006. [CrossRef]

49. Yan, C.; Gu, J.; Hou, D.; Jing, H.; Wang, J.; Guo, Y.; Katsumi, H.; Sakane, T.; Yamamoto, A. Improved tumor targetability of Tat-conjugated PAMAM dendrimers as a novel nanosized anti-tumor drug carrier. Drug Dev. Ind. Pharm. 2014, 41, 617-622. [CrossRef]

50. De La Torre, B.G.; Hornillos, V.; Luque-Ortega, J.R.; Abengozar, M.A.; Amat-Guerri, F.; Acuña, A.U.; Rivas, L.; Andreu, D. A BODIPY-embedding miltefosine analog linked to cell-penetrating Tat(48-60) peptide favors intracellular delivery and visualization of the antiparasitic drug. Amino Acids 2014, 46, 1047-1058. [CrossRef]

51. Zhang, P.; Cheetham, A.G.; Lin, Y.-A.; Cui, H. Self-Assembled Tat Nanofibers as Effective Drug Carrier and Transporter. ACS Nano 2013, 7, 5965-5977. [CrossRef]

52. Fu, B.; Long, W.; Zhang, Y.; Zhang, A.; Miao, F.; Shen, Y.; Pan, N.; Gan, G.; Nie, F.; He, Y.; et al. Enhanced antitumor effects of the BRBP1 compound peptide BRBP1-TAT-KLA on human brain metastatic breast cancer. Sci. Rep. 2015, 5, 8029. [CrossRef]

53. Davoudi, Z.; Akbarzadeh, A.; Rahmatiyamchi, M.; Movassaghpour, A.; Alipour, M.; Nejati-Koshki, K.; Sadeghi, Z.; Dariushnejad, H.; Zarghami, N. Molecular target therapy of AKT and NF-kB signaling pathways and multidrug resistance by specific cell penetrating inhibitor peptides in HL-60 cells. Asian Pac. J. Cancer Prev. 2014, 15, 4353-4358. [CrossRef]

54. Xie, X.; Kerrigan, J.E.; Minko, T.; Garbuzenko, O.; Lee, K.-C.; Scarborough, A.; Abali, E.E.; Budak-Alpdogan, T.; Johnson-Farley, N.; Banerjee, D.; et al. Antitumor and modeling studies of a penetratin-peptide that targets E2F-1 in small cell lung cancer. Cancer Biol. Ther. 2013, 14, 742-751. [CrossRef]

55. Liu, R.; Xi, L.; Luo, D.; Ma, X.; Yang, W.; Xi, Y.; Wang, H.; Qian, M.; Fan, L.; Xia, X.; et al. Enhanced targeted anticancer effects and inhibition of tumor metastasis by the TMTP1 compound peptide TMTP1-TAT-NBD. J. Control. Release 2012, 161, 893-902. [CrossRef]

56. Hotchkiss, R.S.; McConnell, K.W.; Bullok, K.; Davis, C.G.; Chang, K.C.; Schwulst, S.J.; Dunne, J.C.; Dietz, G.P.; Bähr, M.; McDunn, J.; et al. TAT-BH4 and TAT-Bcl-xL peptides protect against sepsis-induced lymphocyte apoptosis in vivo. J. Immunol. 2006, 176, 5471-5477. [CrossRef]

57. Tan, M.; Lan, K.-H.; Yao, J.; Lu, C.-H.; Sun, M.; Neal, C.L.; Lu, J.; Yu, D. Selective Inhibition of ErbB2-Overexpressing Breast CancerIn vivoby a Novel TAT-Based ErbB2-Targeting Signal Transducers and Activators of Transcription 3-Blocking Peptide. Cancer Res. 2006, 66, 3764-3772. [CrossRef]

58. Bidwell, G. Application of thermally responsive polypeptides directed against c-Myc transcriptional function for cancer therapy. Mol. Cancer Ther. 2005, 4, 1076-1085. [CrossRef]

59. Perea, S.E.; Puchades, Y.; Mendoza, O.; Vispo, N.S.; Torrens, I.; Santos, A.; Acevedo, B.; Falcón, V.; Reyes, O.; Silva, R.; et al. Antitumor Effect of a Novel Proapoptotic Peptide that Impairs the Phosphorylation by the Protein Kinase 2 (Casein Kinase 2). Cancer Res. 2004, 64, 7127-7129. [CrossRef]

60. Wang, R.; Wang, H.Y. Enhancement of antitumor immunity by prolonging antigen presentation on dendritic cells. Nat. Biotechnol. 2002, 20, 149-154. [CrossRef]

61. Zhang, T.; Wu, K.; Ding, C.; Sun, K.; Guan, Z.; Wang, X.; Hsieh, J.-T.; He, D.; Fan, J. Inhibiting bladder tumor growth with a cell penetrating R11 peptide derived from the p53 C-terminus. Oncotarget 2015, 6, 37782-37791. [CrossRef]

62. Chu, X.; Wu, B.; Fan, H.; Hou, J.; Hao, J.; Hu, J.; Wang, B.; Liu, G.; Li, C.; Meng, S. PTD-fused p53 as a potential antiviral agent directly suppresses HBV transcription and expression. Antivir. Res. 2016, 127, 41-49. [CrossRef]

63. Wu, Y.; Xie, G.; Xu, Y.; Ma, L.; Tong, C.; Fan, D.; Du, F.; Yu, H. PEP-1-MsrA ameliorates inflammation and reduces atherosclerosis in apolipoprotein E deficient mice. J. Transl. Med. 2015, 13, 316. [CrossRef]

64. Dietz, G.P.; Valbuena, P.C.; Dietz, B.; Meuer, K.; Mueller, P.; Weishaupt, J.H.; Bahr, M. Application of a blood-brain-barrier-penetrating form of GDNF in a mouse model for Parkinson's disease. Brain Res. 2006, 1082, 61-66. [CrossRef] [PubMed]

65. Lee, J.; Jung, E.; Park, J.; Park, D. Transdermal delivery of interferon-gamma (IFN-gamma) mediated by penetratin, a cell-permeable peptide. Biotechnol. Appl. Biochem. 2005, 42, 169-173. [PubMed] 
66. Zahid, M.; Feldman, K.S.; Garcia-Borrero, G.; Feinstein, T.N.; Pogodzinski, N.; Xu, X.; Yurko, R.; Czachowski, M.; Wu, Y.; Mason, N.S.; et al. Cardiac Targeting Peptide, a Novel Cardiac Vector: Studies in Bio-Distribution, Imaging Application, and Mechanism of Transduction. Biomolecules 2018, 8, 147. [CrossRef] [PubMed]

67. Stangl, S.; Tei, L.; De Rose, F.; Reder, S.; Martinelli, J.; Sievert, W.; Shevtsov, M.; Öllinger, R.; Rad, R.; Schwaiger, M.; et al. Preclinical Evaluation of the Hsp70 Peptide Tracer TPP-PEG24-DFO[89Zr] for Tumor-Specific PET/CT Imaging. Cancer Res. 2018, 78, 6268-6281. [CrossRef] [PubMed]

68. Zhao, M.; Yang, W.; Zhang, M.; Li, G.; Wang, S.; Wang, Z.; Ma, X.; Kang, F.; Wang, J. Evaluation of 68Ga-labeled iNGR peptide with tumor-penetrating motif for microPET imaging of CD13-positive tumor xenografts. Tumor Biol. 2016, 37, 12123-12131. [CrossRef]

69. Dong, P.; Cai, H.; Chen, L.; Li, Y.; Yuan, C.; Wu, X.; Shen, G.; Zhou, H.; Zhang, W.; Li, L. Biodistribution and evaluation of131I-labeled neuropilin-binding peptide for targeted tumor imaging. Contrast Media Mol. Imaging 2016, 11, 467-474. [CrossRef]

70. Falanga, A.; Vitiello, M.T.; Cantisani, M.; Tarallo, R.; Guarnieri, D.; Mignogna, E.; Netti, P.A.; Pedone, C.; Galdiero, M.; Galdiero, S. A peptide derived from herpes simplex virus type 1 glycoprotein H: Membrane translocation and applications to the delivery of quantum dots. Nanomed. Nanotechnol. Biol. Med. 2011, 7, 925-934. [CrossRef]

71. Brunetti, J.; Riolo, G.; Gentile, M.; Bernini, A.; Paccagnini, E.; Falciani, C.; Lozzi, L.; Scali, S.; Depau, L.; Pini, A.; et al. Near-infrared quantum dots labelled with a tumor selective tetrabranched peptide for in vivo imaging. J. Nanobiotechnol. 2018, 16, 21. [CrossRef] [PubMed]

72. Avula, U.M.; Yoon, H.K.; Lee, C.H.; Kaur, K.; Ramirez, R.J.; Takemoto, Y.; Ennis, S.R.; Morady, F.; Herron, T.; Berenfeld, O.; et al. Cell-selective arrhythmia ablation for photomodulation of heart rhythm. Sci. Transl. Med. 2015, 7, 311ra172. [CrossRef] [PubMed]

73. Bourré, L.; Giuntini, F.; Eggleston, I.; Mosse, C.A.; MacRobert, A.J.; Wilson, M. Effective photoinactivation of Gram-positive and Gram-negative bacterial strains using an HIV-1 Tat peptide-porphyrin conjugate. Photochem. Photobiol. Sci. 2010, 9, 1613-1620. [CrossRef]

74. Eto, Y.; Yoshioka, Y.; Asavatanabodee, R.; Kida, S.; Maeda, M.; Mukai, Y.; Mizuguchi, H.; Kawasaki, K.; Okada, N.; Nakagawa, S. Transduction of adenovirus vectors modified with cell-penetrating peptides. Peptides 2009, 30, 1548-1552. [CrossRef]

75. Yu, D.; Jin, C.; Ramachandran, M.; Xu, J.; Nilsson, B.; Korsgren, O.; Le Blanc, K.; Uhrbom, L.; Forsberg-Nilsson, K.; Westermark, B.; et al. Adenovirus Serotype 5 Vectors with Tat-PTD Modified Hexon and Serotype 35 Fiber Show Greatly Enhanced Transduction Capacity of Primary Cell Cultures. PLOS ONE 2013, 8, e54952. [CrossRef]

76. Kida, S.; Eto, Y.; Yoshioka, Y.; Nakagawa, S.; Kawasaki, K.; Maeda, M. Evaluation of synthetic cell-penetrating peptides, Pro-rich peptide and octaargine derivatives, as adenovirus vector carrier. Protein Pept. Lett. 2010, 17, 164-167. [CrossRef]

77. Nigatu, A.S.; Vupputuri, S.; Flynn, N.; Neely, B.J.; Ramsey, J.D. Evaluation of Cell-Penetrating Peptide/Adenovirus Particles for Transduction of CAR-Negative Cells. J. Pharm. Sci. 2013, 102, 1981-1993. [CrossRef]

78. Jin, C.; Yu, D.; Cancer, M.; Nilsson, B.; Leja, J.; Essand, M. Tat-PTD-modified oncolytic adenovirus driven by the SCG3 promoter and ASH1 enhancer for neuroblastoma therapy. Hum. Gene Ther. 2013, 24, 766-775. [CrossRef]

79. Ma, X.-C.; Liu, P.; Zhang, X.-L.; Jiang, W.-H.; Jia, M.; Wang, C.-X.; Dong, Y.-Y.; Dang, Y.-H.; Gao, C.-G. Intranasal Delivery of Recombinant AAV Containing BDNF Fused with HA2TAT: A Potential Promising Therapy Strategy for Major Depressive Disorder. Sci. Rep. 2016, 6, 22404. [CrossRef]

80. Wang, G.; Jia, T.; Xu, X.; Chang, L.; Zhang, R.; Fu, Y.; Li, Y.; Yang, X.; Zhang, K.; Lin, G.; et al. Novel miR-122 delivery system based on MS2 virus like particle surface displaying cell-penetrating peptide TAT for hepatocellular carcinoma. Oncotarget 2016, 7, 59402-59416. [CrossRef]

81. Sun, Y.; Sun, Y.; Zhao, R. Establishment of MicroRNA delivery system by PP7 bacteriophage-like particles carrying cell-penetrating peptide. J. Biosci. Bioeng. 2017, 124, 242-249. [CrossRef]

82. Tian, Y.; Zhou, M.; Shi, H.; Gao, S.; Xie, G.; Zhu, M.; Wu, M.; Chen, J.; Niu, Z.-W. Integration of Cell-Penetrating Peptides with Rod-like Bionanoparticles: Virus-Inspired Gene-Silencing Technology. Nano Lett. 2018, 18, 5453-5460. [CrossRef] 
83. Ignatovich, I.A.; Dizhe, E.B.; Pavlotskaya, A.V.; Akifiev, B.N.; Burov, S.V.; Orlov, S.; Perevozchikov, A. Complexes of Plasmid DNA with Basic Domain 47-57 of the HIV-1 Tat Protein Are Transferred to Mammalian Cells by Endocytosis-mediated Pathways. J. Biol. Chem. 2003, 278, 42625-42636. [CrossRef]

84. Rudolph, C.; Plank, C.; Lausier, J.; Schillinger, U.; Müller, R.H.; Rosenecker, J. Oligomers of the Arginine-rich Motif of the HIV-1 TAT Protein Are Capable of Transferring Plasmid DNA into Cells. J. Biol. Chem. 2003, 278, 11411-11418. [CrossRef]

85. Lehto, T.; Simonson, O.E.; Mäger, I.; Ezzat, K.; Sork, H.; Copolovici, D.; Viola, J.R.; Zaghloul, E.; Lundin, P.; Moreno, P.; et al. A Peptide-based Vector for Efficient Gene Transfer in Vitro and in Vivo. Mol. Ther. 2011, 19, 1457-1467. [CrossRef]

86. Zhang, W.; Song, J.; Liang, R.; Zheng, X.; Chen, J.; Li, G.; Zhang, B.; Wang, K.; Yan, X.; Wang, R. Stearylated antimicrobial peptide [D]-K6L9 with cell penetrating property for efficient gene transfer. Peptides 2013, 46, 33-39. [CrossRef]

87. Cardoso, A.M.; Trabulo, S.; Cardoso, A.L.; Maia, S.; Gomes, P.A.C.; Jurado, A.S.; De Lima, M.C.P. Comparison of the Efficiency of Complexes Based on S413-PV Cell-Penetrating Peptides in Plasmid DNA and siRNA Delivery. Mol. Pharm. 2013, 10, 2653-2666. [CrossRef]

88. Alhakamy, N.A.; Ishiguro, S.; Uppalapati, D.; Berkland, C.; Tamura, M. AT2R Gene Delivered by Condensed Polylysine Complexes Attenuates Lewis Lung Carcinoma after Intravenous Injection or Intratracheal Spray. Mol. Cancer Ther. 2015, 15, 209-218. [CrossRef]

89. Qu, W.; Chen, W.-H.; Kuang, Y.; Zeng, X.; Cheng, S.-X.; Zhou, X.; Zhuo, R.-X.; Zhang, X.-Z. Avidin-Biotin Interaction Mediated Peptide Assemblies as Efficient Gene Delivery Vectors for Cancer Therapy. Mol. Pharm. 2012, 10, 261-269. [CrossRef]

90. Gong, C.; Pan, D.; Qiu, F.; Sun, P.; Zhang, Y.-H. Selective DNA Delivery to Tumor Cells Using an Oligoarginine-LTVSPWY Peptide. PLoS ONE 2014, 9, e110632. [CrossRef]

91. Wang, H.; Wang, H.; Liang, J.; Jiang, Y.; Guo, Q.; Peng, H.; Xu, Q.; Huang, Y. Cell-Penetrating Apoptotic Peptide/p53 DNA Nanocomplex as Adjuvant Therapy for Drug-Resistant Breast Cancer. Mol. Pharm. 2014, 11, 3352-3360. [CrossRef] [PubMed]

92. Nam, H.Y.; Kim, J.; Kim, S.W.; Bull, D.A. Cell Targeting Peptide Conjugation to siRNA Polyplexes for Effective Gene Silencing in Cardiomyocytes. Mol. Pharm. 2012, 9, 1302-1309. [CrossRef] [PubMed]

93. Li, H.; Zheng, X.; Koren, V.; Vashist, Y.K.; Tsui, T.Y. Highly efficient delivery of siRNA to a heart transplant model by a novel cell penetrating peptide-dsRNA binding domain. Int. J. Pharm. 2014, 469, 206-213. [CrossRef] [PubMed]

94. Ruan, W.; Zhai, Y.; Yu, K.; Wu, C.; Xu, Y. Coated microneedles mediated intradermal delivery of octaarginine/BRAF siRNA nanocomplexes for anti-melanoma treatment. Int. J. Pharm. 2018, 553, 298-309. [CrossRef] [PubMed]

95. Uchida, T.; Kanazawa, T.; Kawai, M.; Takashima, Y.; Okada, H. Therapeutic Effects on Atopic Dermatitis by Anti-RelA Short Interfering RNA Combined with Functional Peptides Tat and AT1002. J. Pharmacol. Exp. Ther. 2011, 338, 443-450. [CrossRef] [PubMed]

96. Freire, J.M.; De Figueiredo, I.R.; Valle, J.; Veiga, A.S.; Andreu, D.; Enguita, F.J.; Castanho, M.A.R.B. siRNA-cell-penetrating peptides complexes as a combinatorial therapy against chronic myeloid leukemia using BV173 cell line as model. J. Control. Release 2017, 245, 127-136. [CrossRef]

97. Suh, J.S.; Lee, H.J.; Nam, H.; Jo, B.S.; Lee, D.W.; Kim, J.-H.; Lee, J.Y.; Chung, C.P.; Lee, G.; Park, Y.J. Control of cancer stem cell like population by intracellular target identification followed by the treatment with peptide-siRNA complex. Biochem. Biophys. Res. Commun. 2017, 491, 827-833. [CrossRef]

98. Tuttolomondo, M.; Casella, C.; Hansen, P.L.; Polo, E.; Herda, L.M.; Dawson, K.A.; Ditzel, H.J.; Mollenhauer, J. Human DMBT1-Derived Cell-Penetrating Peptides for Intracellular siRNA Delivery. Mol. Ther. Nucleic Acids 2017, 8, 264-276. [CrossRef]

99. Morais, C.; Cardoso, A.M.; Cunha, P.; Aguiar, L.; Vale, N.; Lage, E.V.; Pinheiro, M.; Nunes, C.; Gomes, P.A.C.; Reis, S.; et al. Acylation of the S413-PV cell-penetrating peptide as a means of enhancing its capacity to mediate nucleic acid delivery: Relevance of peptide/lipid interactions. Biochim. Biophys. Acta (BBA) Biomembr. 2018, 1860, 2619-2634. [CrossRef]

100. Tai, Z.; Wang, X.; Tian, J.; Gao, Y.; Zhang, L.; Yao, C.; Wu, X.; Zhang, W.; Zhu, Q.; Gao, S. Biodegradable Stearylated Peptide with Internal Disulfide Bonds for Efficient Delivery of siRNA In Vitro and In Vivo. Biomacromolecules 2015, 16, 1119-1130. [CrossRef] 
101. Liu, Y.; Wu, X.; Gao, Y.; Zhang, J.; Zhang, D.; Gu, S.; Zhu, G.; Liu, G.-L.; Li, X.-Y. Aptamer-functionalized peptide H3CR5C as a novel nanovehicle for codelivery of fasudil and miRNA-195 targeting hepatocellular carcinoma. Int. J. Nanomed. 2016, 11, 3891-3905. [CrossRef]

102. Lo, J.H.; Hao, L.; Muzumdar, M.; Raghavan, S.; Kwon, E.J.; Pulver, E.M.; Hsu, F.; Aguirre, A.J.; Wolpin, B.M.; Fuchs, C.S.; et al. iRGD-guided Tumor-penetrating Nanocomplexes for Therapeutic siRNA Delivery to Pancreatic Cancer. Mol. Cancer Ther. 2018, 17, 2377-2388. [CrossRef] [PubMed]

103. Alexander-Bryant, A.A.; Zhang, H.; Attaway, C.C.; Pugh, W.; Eggart, L.; Sansevere, R.M.; Andino, L.M.; Dinh, L.; Cantini, L.P.; Jakymiw, A. Dual peptide-mediated targeted delivery of bioactive siRNAs to oral cancer cells in vivo. Oral Oncol. 2017, 72, 123-131. [CrossRef] [PubMed]

104. Bao, Y.; Guo, H.; Lu, Y.; Feng, W.; Sun, X.; Tang, C.; Wang, X.; Shen, M. Blocking hepatic metastases of colon cancer cells using an shRNA against Rac1 delivered by activatable cell-penetrating peptide. Oncotarget 2016, 7, 77183-77195. [CrossRef]

105. Yang, Y.; Xia, X.; Dong, W.; Wang, H.; Li, L.; Ma, P.; Sheng, W.; Xu, X.; Liu, Y. Acid Sensitive Polymeric Micelles Combining Folate and Bioreducible Conjugate for Specific Intracellular siRNA Delivery. Macromol. Biosci. 2016, 16, 759-773. [CrossRef] [PubMed]

106. Jiang, Q.-Y.; Lai, L.-H.; Shen, J.; Wang, Q.-Q.; Xu, F.-J.; Tang, G. Gene delivery to tumor cells by cationic polymeric nanovectors coupled to folic acid and the cell-penetrating peptide octaarginine. Biomaterials 2011, 32, 7253-7262. [CrossRef]

107. Ye, S.; Tian, M.-M.; Wang, T.-X.; Ren, L.; Wang, N.; Shen, L.; Shang, T. Synergistic effects of cell-penetrating peptide Tat and fusogenic peptide HA2-enhanced cellular internalization and gene transduction of organosilica nanoparticles. Nanomed. Nanotechnol. Biol. Med. 2012, 8, 833-841. [CrossRef] [PubMed]

108. Huang, S.; Shao, K.; Liu, Y.; Kuang, Y.; Li, J.; An, S.; Guo, Y.; Ma, H.; Jiang, C. Tumor-Targeting and Microenvironment-Responsive Smart Nanoparticles for Combination Therapy of Antiangiogenesis and Apoptosis. ACS Nano 2013, 7, 2860-2871. [CrossRef]

109. Yang, Y.; Xie, X.; Yang, Y.; Li, Z.; Yu, F.; Gong, W.; Li, Y.; Zhang, H.; Wang, Z.; Mei, X. Polymer Nanoparticles Modified with Photo- and $\mathrm{pH}$-Dual-Responsive Polypeptides for Enhanced and Targeted Cancer Therapy. Mol. Pharm. 2016, 13, 1508-1519. [CrossRef]

110. Osman, G.; Rodriguez, J.; Chan, S.Y.; Chisholm, J.; Duncan, G.; Kim, N.; Tatler, A.L.; Shakesheff, K.M.; Hanes, J.; Suk, J.S.; et al. PEGylated enhanced cell penetrating peptide nanoparticles for lung gene therapy. J. Control. Release 2018, 285, 35-45. [CrossRef]

111. Dowaidar, M.; Abdelhamid, H.N.; Hällbrink, M.; Freimann, K.; Kurrikoff, K.; Zou, X.; Langel, Ü. Magnetic Nanoparticle Assisted Self-assembly of Cell Penetrating Peptides-Oligonucleotides Complexes for Gene Delivery. Sci. Rep. 2017, 7, 9159. [CrossRef] [PubMed]

112. Ben Djemaa, S.; David, S.; Aubert, K.H.; Falanga, A.; Galdiero, S.; Allard-Vannier, E.; Chourpa, I.; Munnier, E. Formulation and in vitro evaluation of a siRNA delivery nanosystem decorated with gH625 peptide for triple negative breast cancer theranosis. Eur. J. Pharm. Biopharm. 2018, 131, 99-108. [CrossRef] [PubMed]

113. Peng, L.-H.; Niu, J.; Zhang, C.-Z.; Yu, W.; Wu, J.-H.; Shan, Y.-H.; Wang, X.-R.; Shen, Y.; Mao, Z.; Liang, W.; et al. TAT conjugated cationic noble metal nanoparticles for gene delivery to epidermal stem cells. Biomaterials 2014, 35, 5605-5618. [CrossRef] [PubMed]

114. Park, H.; Tsutsumi, H.; Mihara, H. Cell penetration and cell-selective drug delivery using $\alpha$-helix peptides conjugated with gold nanoparticles. Biomaterials 2013, 34, 4872-4879. [CrossRef] [PubMed]

115. Wonder, E.; Simón-Gracia, L.; Scodeller, P.; Majzoub, R.N.; Kotamraju, V.R.; Ewert, K.; Teesalu, T.; Safinya, C. Competition of charge-mediated and specific binding by peptide-tagged cationic liposome-DNA nanoparticles in vitro and in vivo. Biomaterials 2018, 166, 52-63. [CrossRef] [PubMed]

116. Fisher, R.K.; Mattern-Schain, S.I.; Best, M.D.; Kirkpatrick, S.S.; Freeman, M.B.; Grandas, O.H.; Mountain, D.J. Improving the efficacy of liposome-mediated vascular gene therapy via lipid surface modifications. J. Surg. Res. 2017, 219, 136-144. [CrossRef]

117. Fu, H.; Shi, K.; Hu, G.; Yang, Y.; Kuang, Q.; Lu, L.; Zhang, L.; Chen, W.; Dong, M.; Chen, Y.; et al. Tumor-Targeted Paclitaxel Delivery and Enhanced Penetration Using TAT-Decorated Liposomes Comprising Redox-Responsive Poly(Ethylene Glycol). J. Pharm. Sci. 2015, 104, 1160-1173. [CrossRef]

118. Liu, Z.; Xiong, M.; Gong, J.; Zhang, Y.; Bai, N.; Luo, Y.; Li, L.; Wei, Y.; Liu, Y.; Tan, X.; et al. Legumain protease-activated TAT-liposome cargo for targeting tumours and their microenvironment. Nat. Commun. 2014, 5, 4280. [CrossRef] 
119. Seeman, N.C. Nucleic acid junctions and lattices. J. Theor. Biol. 1982, 99, 237-247. [CrossRef]

120. Rothemund, P.W.K. Folding DNA to create nanoscale shapes and patterns. Nature 2006, 440, $297-302$. [CrossRef]

121. Yin, P.; Hariadi, R.; Sahu, S.; Choi, H.; Park, S.H.; LaBean, T.; Reif, J.H. Programming DNA Tube Circumferences. Science 2008, 321, 824-826. [CrossRef] [PubMed]

122. Rothemund, P.W.K.; Ekani-Nkodo, A.; Papadakis, N.; Kumar, A.; Fygenson, D.K.; Winfree, E. Design and Characterization of Programmable DNA Nanotubes. J. Am. Chem. Soc. 2004, 126, 16344-16352. [CrossRef] [PubMed]

123. Ke, Y.; Ong, L.L.; Sun, W.; Song, J.; Dong, M.; Shih, W.M.; Yin, P. DNA brick crystals with prescribed depths. Nat. Chem. 2014, 6, 994-1002. [CrossRef] [PubMed]

124. Ke, Y.; Ong, L.L.; Shih, W.M.; Yin, P. Three-Dimensional Structures Self-Assembled from DNA Bricks. Science 2012, 338, 1177-1183. [CrossRef] [PubMed]

125. Sacca, B.; Niemeyer, C.M. Functionalization of DNA nanostructures with proteins. Chem. Soc. Rev. 2011, 40, 5910. [CrossRef] [PubMed]

126. Sacca, B.; Meyer, R.; Erkelenz, M.; Kiko, K.; Arndt, A.; Schroeder, H.; Rabe, K.S.; Niemeyer, C.M. Orthogonal protein decoration of DNA origami. Angew. Chem. Int. Ed. Engl. 2010, 49, 9378-9383. [CrossRef]

127. Schaffert, D.H.; Okholm, A.H.; Sørensen, R.S.; Nielsen, J.S.; Tørring, T.; Rosen, C.B.; Kodal, A.L.B.; Mortensen, M.R.; Gothelf, K.V.; Kjems, J. Intracellular Delivery of a Planar DNA Origami Structure by the Transferrin-Receptor Internalization Pathway. Small 2016, 12, 2634-2640. [CrossRef]

128. Liu, J.; Song, L.; Liu, S.; Jiang, Q.; Liu, Q.; Li, N.; Wang, Z.-G.; Ding, B. A DNA-Based Nanocarrier for Efficient Gene Delivery and Combined Cancer Therapy. Nano Lett. 2018, 18, 3328-3334. [CrossRef]

129. Madhanagopal, B.R.; Zhang, S.; Demirel, E.; Wady, H.; Chandrasekaran, A.R. DNA Nanocarriers: Programmed to Deliver. Trends Biochem. Sci. 2018, 43, 997-1013. [CrossRef]

130. Yan, J.; Hu, C.; Wang, P.; Zhao, B.; Ouyang, X.; Zhou, J.; Liu, R.; He, D.; Fan, C.; Song, S. Growth and origami folding of DNA on nanoparticles for high-efficiency molecular transport in cellular imaging and drug delivery. Angew. Chem. Int. Ed. Engl. 2015, 54, 2431-2435. [CrossRef]

131. Guo, X.-L.; Yuan, D.-D.; Song, T.; Li, X.-M. DNA nanopore functionalized with aptamer and cell-penetrating peptide for tumor cell recognition. Anal. Bioanal. Chem. 2017, 4, 713-797. [CrossRef]

132. Lee, H.; Lytton-Jean, A.; Chen, Y.; Love, K.T.; Park, A.I.; Karagiannis, E.; Sehgal, A.; Querbes, W.; Zurenko, C.S.; Jayaraman, M.; et al. Molecularly self-assembled nucleic acid nanoparticles for targeted in vivo siRNA delivery. Nat. Nanotechnol. 2012, 7, 389-393. [CrossRef] [PubMed]

133. Tan, X.; Bruchez, M.P.; Armitage, B. Closing the Loop: Constraining TAT Peptide by $\gamma$ PNA Hairpin for Enhanced Cellular Delivery of Biomolecules. Bioconjug. Chem. 2018, 29, 2892-2898. [CrossRef]

134. Liu, Y.; Kumar, S.; Taylor, R. Mix-and-match nanobiosensor design: Logical and spatial programming of biosensors using self-assembled DNA nanostructures. Wiley Interdiscip. Rev. Nanomed. Nanobiotechnol. 2018, 10, e1518. [CrossRef] [PubMed]

135. Ijäs, H.; Nummelin, S.; Shen, B.; Kostiainen, M.A.; Linko, V. Dynamic DNA Origami Devices: From Strand-Displacement Reactions to External-Stimuli Responsive Systems. Int. J. Mol. Sci. 2018, 19, 2114. [CrossRef] [PubMed]

136. Nielsen, P.; Egholm, M.; Berg, R.; Buchardt, O. Sequence-selective recognition of DNA by strand displacement with a thymine-substituted polyamide. Science 1991, 254, 1497-1500. [CrossRef]

137. Demidov, V.V.; Potaman, V.N.; Frank-Kamenetskil, M.; Egholm, M.; Buchard, O.; Sönnichsen, S.H.; Nlelsen, P.E. Stability of peptide nucleic acids in human serum and cellular extracts. Biochem. Pharmacol. 1994, 48, 1310-1313. [CrossRef]

138. Takiya, T.; Seto, Y.; Yasuda, H.; Suzuki, T.; Kawai, K. An empirical approach for thermal stability (Tm) prediction of PNA/DNA duplexes. Nucleic Acids Symp. Ser. 2004, 48, 131-132. [CrossRef]

139. Uhlmann, E.; Peyman, A.; Breipohl, G.; Will, D.W. PNA. Synthetic Polyamide Nucleic Acids with Unusual Binding Properties. Angew. Chem. Int. Ed. Engl. 1998, 37, 2796-2823. [CrossRef]

140. Eriksson, M.; Nielsen, P.E. PNA-nucleic acid complexes. Structure, stability and dynamics. Q. Rev. Biophys. 1996, 29, 369-394. [CrossRef] 
141. Sahu, B.; Sacui, I.; Rapireddy, S.; Zanotti, K.J.; Bahal, R.; Armitage, B.A.; Ly, D.H. Synthesis and characterization of conformationally preorganized, (R)-diethylene glycol-containing gamma-peptide nucleic acids with superior hybridization properties and water solubility. J. Org. Chem. 2011, 76, 5614-5627. [CrossRef] [PubMed]

142. Nielsen, P.E. Addressing the challenges of cellular delivery and bioavailability of peptide nucleic acids (PNA). Q. Rev. Biophys. 2005, 38, 345-350. [CrossRef] [PubMed]

143. Koppelhus, U.; Awasthi, S.K.; Zachar, V.; Holst, H.U.; Ebbesen, P.; Nielsen, P.E. Cell-Dependent Differential Cellular Uptake of PNA, Peptides, and PNA-Peptide Conjugates. Antisense Nucleic Acid Drug Dev. 2002, 12, 51-63. [CrossRef] [PubMed]

144. Egholm, M.; Buchardt, O.; Christensen, L.; Behrens, C.; Freier, S.M.; Driver, D.A.; Berg, R.H.; Kim, S.K.; Norden, B.; Nielsen, P.E. PNA hybridizes to complementary oligonucleotides obeying the Watson-Crick hydrogen-bonding rules. Nature 1993, 365, 566-568. [CrossRef] [PubMed]

145. Shiraishi, T.; Nielsen, P.E. Cellular Delivery of Peptide Nucleic Acids (PNAs). Adv. Struct. Saf. Stud. 2013, 1050, 193-205.

146. Quijano, E.; Bahal, R.; Ricciardi, A.; Saltzman, W.M.; Glazer, P.M. Therapeutic Peptide Nucleic Acids: Principles, Limitations, and Opportunities. Yale J. Biol. Med. 2017, 90, 583-598.

147. Pooga, M.; Soomets, U.; Hällbrink, M.; Valkna, A.; Saar, K.; Rezaei, K.; Kahl, U.; Hao, J.-X.; Xu, X.-J.; Wiesenfeld-Hallin, Z.; et al. Cell penetrating PNA constructs regulate galanin receptor levels and modify pain transmission in vivo. Nat. Biotechnol. 1998, 16, 857-861. [CrossRef]

148. Aldrian-Herrada, G.; Desarmenien, M.G.; Orcel, H.; Boissin-Agasse, L.; Mery, J.; Brugidou, J.; Rabie, A. A peptide nucleic acid (PNA) is more rapidly internalized in cultured neurons when coupled to a retro-inverso delivery peptide. The antisense activity depresses the target mRNA and protein in magnocellular oxytocin neurons. Nucleic Acids Res. 1998, 26, 4910-4916. [CrossRef]

149. Dragulescu-Andrasi, A.; Rapireddy, S.; He, G.; Bhattacharya, B.; Hyldig-Nielsen, J.J.; Zon, G.; Ly, D.H. Cell-permeable peptide nucleic acid designed to bind to the 5 -untranslated region of E-cadherin transcript induces potent and sequence-specific antisense effects. J. Am. Chem. Soc. 2006, 128, 16104-16112. [CrossRef]

150. Dragulescu-Andrasi, A.; Rapireddy, S.; Frezza, B.M.; Gayathri, C.; Gil, R.R.; Ly, D.H. A Simple $\gamma$-Backbone Modification Preorganizes Peptide Nucleic Acid into a Helical Structure. J. Am. Chem. Soc. 2006, 128, 10258-10267. [CrossRef]

151. Rogers, F.A.; Lin, S.S.; Hegan, D.C.; Krause, D.S.; Glazer, P.M. Targeted Gene Modification of Hematopoietic Progenitor Cells in Mice Following Systemic Administration of a PNA-peptide Conjugate. Mol. Ther. 2011, 20, 109-118. [CrossRef] [PubMed]

152. Shiraishi, T.; Pankratova, S.; Nielsen, P.E. Calcium Ions Effectively Enhance the Effect of Antisense Peptide Nucleic Acids Conjugated to Cationic Tat and Oligoarginine Peptides. Chem. Biol. 2005, 12, 923-929. [CrossRef] [PubMed]

153. Babar, I.A.; Cheng, C.J.; Booth, C.J.; Liang, X.; Weidhaas, J.; Saltzman, W.M.; Slack, F.J. Nanoparticle-based therapy in an in vivo microRNA-155 (miR-155)-dependent mouse model of lymphoma. Proc. Natl. Acad. Sci. USA 2012, 109, E1695-E1704. [CrossRef] [PubMed]

154. Wang, H.-X.; Song, Z.; Lao, Y.-H.; Xu, X.; Gong, J.; Cheng, D.; Chakraborty, S.; Park, J.S.; Li, M.; Huang, D.; et al. Nonviral gene editing via CRISPR/Cas9 delivery by membrane-disruptive and endosomolytic helical polypeptide. Proc. Natl. Acad. Sci. USA 2018, 115, 4903-4908. [CrossRef]

155. Lostalé-Seijo, I.; Louzao, I.; Juanes, M.; Montenegro, J. Peptide/Cas9 nanostructures for ribonucleoprotein cell membrane transport and gene edition. Chem. Sci. 2017, 8, 7923-7931.

156. Ramakrishna, S.; Dad, A.-B.K.; Beloor, J.; Gopalappa, R.; Lee, S.-K.; Kim, H.H. Gene disruption by cell-penetrating peptide-mediated delivery of Cas9 protein and guide RNA. Genome Res. 2014, 24, 1020-1027. [CrossRef]

157. Del'Guidice, T.; Lepetit-Stoffaes, J.P.; Bordeleau, L.J.; Roberge, J.; Theberge, V.; Lauvaux, C.; Barbeau, X.; Trottier, J.; Dave, V.; Roy, D.C.; et al. Membrane permeabilizing amphiphilic peptide delivers recombinant transcription factor and CRISPR-Cas9/Cpf1 ribonucleoproteins in hard-to-modify cells. PLoS ONE 2018, 13, e0195558. [CrossRef]

158. Suresh, B.; Ramakrishna, S.; Kim, H.H. Cell-Penetrating Peptide-Mediated Delivery of Cas9 Protein and Guide RNA for Genome Editing. Adv. Struct. Saf. Stud. 2016, 1507, 81-94. 
159. Coriat, R.; Faivre, S.; Mir, O.; Dreyer, C.; Ropert, S.; Bouattour, M.; Desjardins, R.; Goldwasser, F.; Raymond, E. Pharmacokinetics and safety of DTS-108, a human oligopeptide bound to SN-38 with an esterase-sensitive cross-linker in patients with advanced malignancies: A Phase I study. Int. J. Nanomed. 2016, 11, 6207-6216. [CrossRef]

160. Lulla, R.R.; Goldman, S.; Yamada, T.; Beattie, C.W.; Bressler, L.; Pacini, M.; Pollack, I.F.; Fisher, P.G.; Packer, R.J.; Dunkel, I.J.; et al. Phase I trial of p28 (NSC745104), a non-HDM2-mediated peptide inhibitor of p53 ubiquitination in pediatric patients with recurrent or progressive central nervous system tumors: A Pediatric Brain Tumor Consortium Study. Neuro Oncol. 2016, 18, 1319-1325. [CrossRef]

161. Warso, M.A.; Richards, J.M.; Mehta, D.; Christov, K.; Schaeffer, C.; Bressler, L.R.; Yamada, T.; Majumdar, D.; Kennedy, S.; Beattie, C.W.; et al. A first-in-class, first-in-human, phase I trial of p28, a non-HDM2-mediated peptide inhibitor of p53 ubiquitination in patients with advanced solid tumours. Br. J. Cancer 2013, 108, 1061-1070. [CrossRef] [PubMed]

162. Unkart, J.T.; Wapnir, I.L.; E González, J.; Harootunian, A.; Wallace, A.M.; Chen, S.L. Intraoperative Tumor Detection Using a Ratiometric Activatable Fluorescent Peptide: A First-in-Human Phase 1 Study. Ann. Surg. Oncol. 2017, 24, 3167-3173. [CrossRef] [PubMed]

163. Gurbel, P.A.; Bliden, K.P.; Turner, S.E.; Tantry, U.S.; Gesheff, M.G.; Barr, T.P.; Covic, L.; Kuliopulos, A. Cell-Penetrating Pepducin Therapy Targeting PAR1 in Subjects with Coronary Artery Disease. Arter. Thromb. Vasc. Biol. 2016, 36, 189-197. [CrossRef] [PubMed]

164. Qian, Z.; Martyna, A.; Hard, R.L.; Wang, J.; Appiah-Kubi, G.; Coss, C.; Phelps, M.; Rossman, J.; Pei, D. Discovery and Mechanism of Highly Efficient Cyclic Cell-Penetrating Peptides. Biochemistry 2016, 55, 2601-2612. [CrossRef]

165. Pooga, M.; Hallbrink, M.; Zorko, M.; Langle, U. Cell penetration by transportan. FASEB J. 1998, 12 , 67-77. [CrossRef]

166. Robbins, P.F.; A Kantor, J.; Salgaller, M.; Hand, P.H.; Fernsten, P.D.; Schlom, J. Transduction and expression of the human carcinoembryonic antigen gene in a murine colon carcinoma cell line. Cancer Res. 1991, 51, 3657-3662.

167. Jones, S.; Farquhar, M.; Martin, A.; Howl, J. Intracellular translocation of the decapeptide carboxyl terminal of Gi3 alpha induces the dual phosphorylation of p42/p44 MAP kinases. Biochim. Biophys. Acta 2005, 1745, 207-214. [CrossRef]

168. Gao, C.; Mao, S.; Ditzel, H.J.; Farnaes, L.; Wirsching, P.; Lerner, R.A.; Janda, K.D. A cell-penetrating peptide from a novel pVII-pIX phage-displayed random peptide library. Bioorg. Med. Chem. 2002, 10, 4057-4065. [CrossRef]

169. Lim, J.; Kim, J.; Duong, T.; Lee, G.; Yoon, J.; Kim, H.; Ruley, H.E.; El-Rifai, W.; Jo, D. Antitumor activity of cell-permeable p18(INK4c) with enhanced membrane and tissue penetration. Mol. Ther. 2012, 20, 1540-1549. [CrossRef]

170. Lim, J.; Duong, T.; Do, N.; Do, P.; Kim, J.; Kim, H.; El-Rifai, W.; Ruley, H.E.; Jo, D. Antitumor activity of cell-permeable RUNX3 protein in gastric cancer cells. Clin. Cancer Res. 2013, 19, 680-690. [CrossRef]

171. Findlay, D.M.; Houssami, S.; Lin, H.Y.; Myers, D.E.; Brady, C.L.; Darcy, P.K.; Ikeda, K.; Martin, T.J.; Sexton, P.M. Truncation of the porcine calcitonin receptor cytoplasmic tail inhibits internalization and signal transduction but increases receptor affinity. Mol. Endocrinol. 1994, 8, 1691-1700. [PubMed]

172. Sadler, K.; Eom, K.D.; Yang, J.-L.; Dimitrova, Y.; Tam, J.P. Translocating Proline-Rich Peptides from the Antimicrobial Peptide Bactenecin 7. Biochemistry 2002, 41, 14150-14157. [CrossRef] [PubMed]

173. McConnell, S.J.; Thon, V.J.; Spinella, D.G. Isolation of fibroblast growth factor receptor binding sequences using evolved phage display libraries. Comb. Chem. High Throughput Screen. 1999, 2, 155-163. [PubMed]

174. Zong, X.; Jiang, D.-Y.; Li, G.-J.; Cai, J.-L. Construction of keratinocyte growth factor phage active peptides for the promotion of epidermal cell proliferation. Zhonghua Yi Xue Za Zhi 2013, 1058-1062. [CrossRef]

(C) 2020 by the authors. Licensee MDPI, Basel, Switzerland. This article is an open access article distributed under the terms and conditions of the Creative Commons Attribution (CC BY) license (http://creativecommons.org/licenses/by/4.0/). 